Universidad de Lima

Escuela de Posgrado

Maestría en Derecho Empresarial

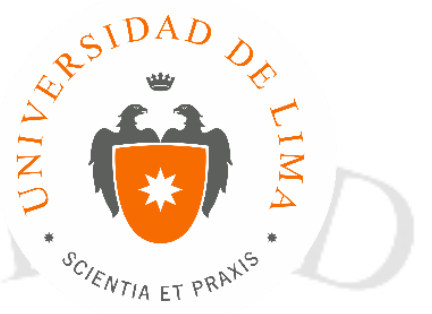

\title{
REGIMEN TRIBUTARIO APLICABLE A LOS INSUMOS QUIMICOS Y BIENES INCAUTADOS AL AMPARO DEL DECRETO LEGISLATIVO $\mathbf{N}^{\circ} 1126$
}

Trabajo de investigación para optar el Grado Académico de Maestro en Derecho Empresarial

\section{Marcia Gisele Bellido Luglio \\ Código 821840}

\author{
Lima - Perú \\ Marzo de 2016
}




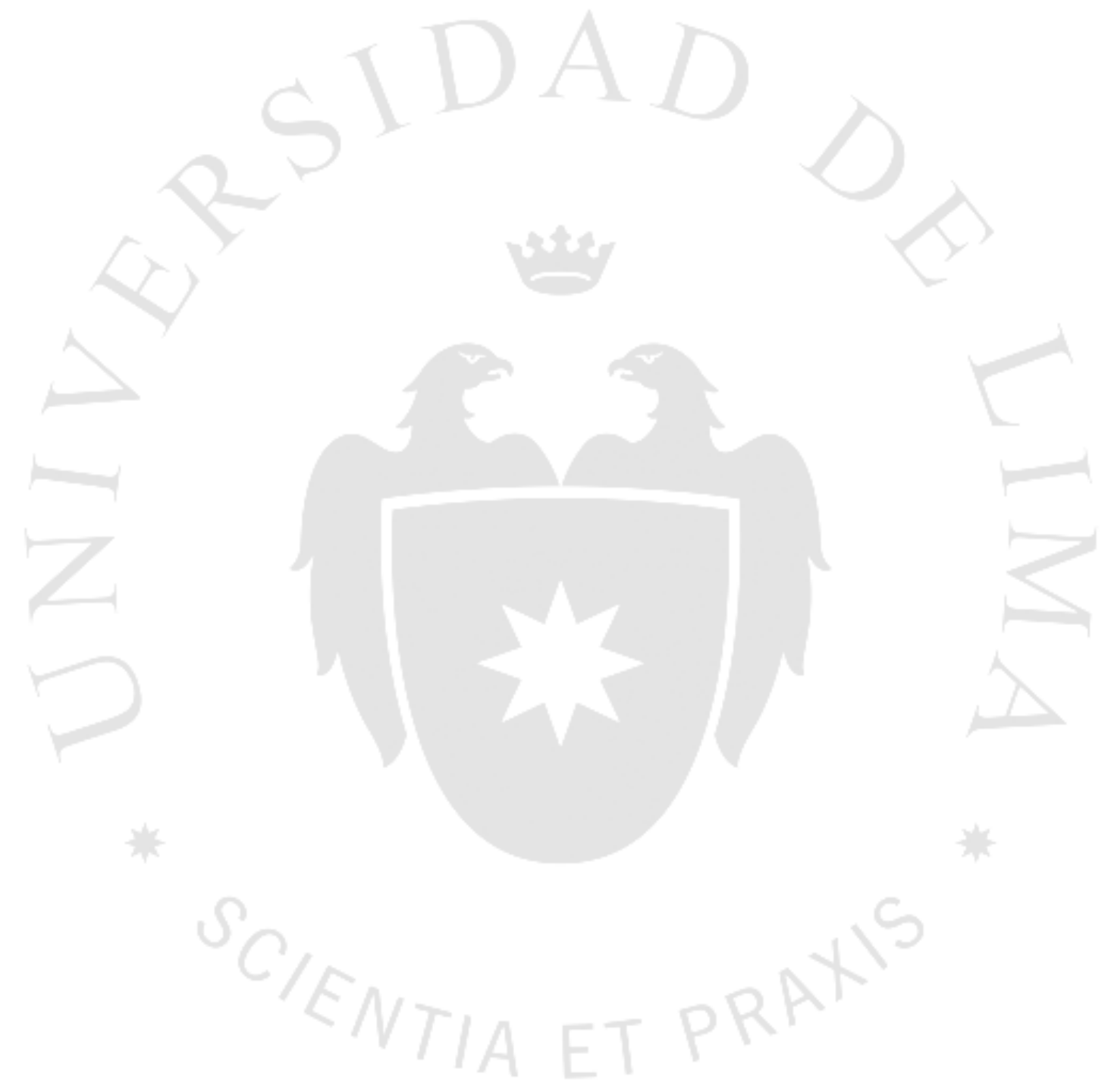




\section{REGIMEN TRIBUTARIO APLICABLE A LOS INSUMOS QUIMICOS Y BIENES}

\section{INCAUTADOS AL AMPARO DEL DECRETO}

LEGISLATIVO $\mathbf{N}^{\circ} 1126$ 


\section{TABLA DE CONTENIDO}

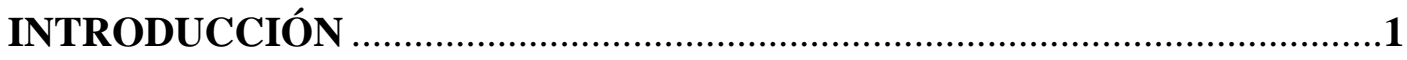

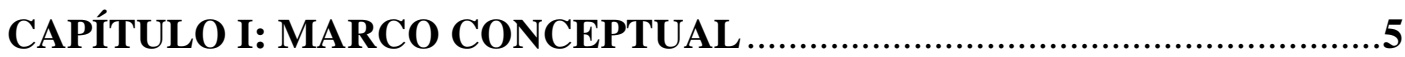

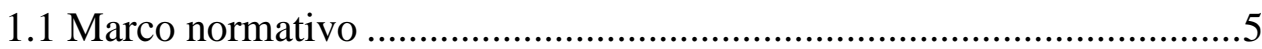

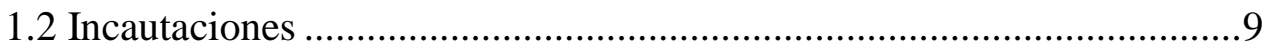

CAPÍTULO II: REGIMEN TRIBUTARIO APLICABLE ..............................15

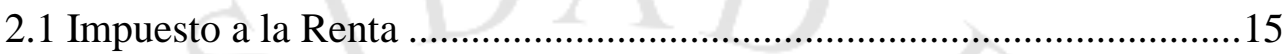

2.1.1 Bienes adquiridos con el producto de actividades lícitas ....................16

2.1.2 Bienes adquiridos con el producto de actividades ilícitas ..................30

2.1.3 Bienes incautados que no pertenecen al Usuario................................32

2.2 Impuesto General a las Ventas .............................................................33

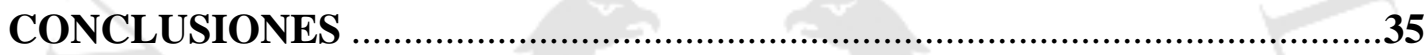

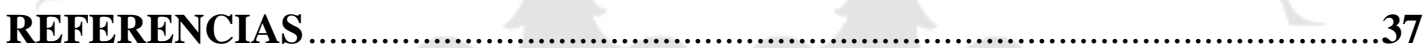




\section{ÍNDICE DE FIGURAS}

Figura 0. 1 Comisos, Incautaciones e Inmovilizaciones $2000-2015 \ldots \ldots \ldots \ldots \ldots \ldots \ldots \ldots . . . . \ldots$

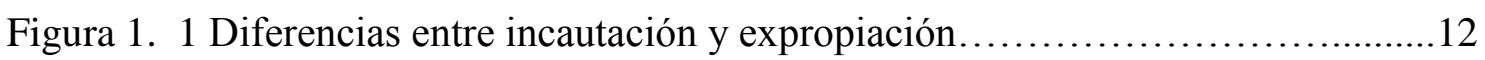




\section{INTRODUCCIÓN}

Según la Comisión Nacional para el Desarrollo y Vida sin Drogas - DEVIDA (2014), la demanda de alrededor de 20 millones de consumidores de cocaína (mayoritariamente de Europa, Asia y los Estados Unidos) es atendida con los 440 TM de clorhidrato de cocaína, por la que los consumidores pagan 85,000 millones de dólares (p. 66).

De acuerdo a la información de la Oficina de las Naciones Unidas contra el Delito y las Drogas - UNODC, la mayor parte de esta cantidad de cocaína se produce en Colombia (42\%), Perú (39\%) y Bolivia (19\%). Sin embargo, cifras reveladas por los Estados Unidos de Norteamérica en el mes de octubre de 2011 informan que el país ha superado a Colombia como exportador de Cocaína (como se citó en DEVIDA, 2014, p. 66).

La producción de hoja de coca en el país se ha venido incrementando sustancialmente desde los años 90, llegando a alcanzar, durante el año 2010 la cantidad de 129,500 TM, la cual representa 14.4 veces la demanda legal estimada en 9,000 TM, por lo que la diferencia está dirigida al tráfico ilícito de drogas (DEVIDA, 2015, p.70).

En ese contexto, la estrategia de la lucha contra las drogas plantea el control de insumos químicos, partiendo de la premisa de su necesaria presencia en la elaboración de la droga.

En efecto, la producción de cocaína requiere:

1. Conversión de la hoja de coca en Pasta Básica de Cocaína (PBC)

Proceso que empieza con la maceración de las hojas de coca en Ácido Sulfúrico diluido en agua, para extraer el alcaloide. El líquido resultante es vertido en una poza de decantación y se mezcla con Kerosene.

Luego de añadirle más Ácido Sulfúrico se genera una nueva decantación de la que resulta el sulfato de cocaína. A este producto se le agrega carbonato de sodio y se deja secar.

2. Conversión de la PBC en Pasta Básica Lavada de Cocaína (PBL)

Se muele y diluye la PBC en una olla de fuego y se agrega Ácido Sulfúrico. Luego se añade Permanganato de Potasio para oxidar la droga y quemar 
impurezas. Finalmente, se agrega Carbonato de Sodio para que la pasta se vuelva sólida.

3. Conversión de la Pasta Básica Lavada de Cocaína en Clorhidrato de Cocaína

Para culminar el proceso de producción, la PBL se diluye con Acetona, se filtra y se le añade Ácido Clorhídrico.

Como puede apreciarse, en todo el procese detallado se requieren, cuando menos los siguientes Insumos Químicos: Ácido Sulfúrico, Kerosene, Carbonato de Sodio, Permanganato de Potasio, Acetona y Ácido Clorhídrico.

No obstante lo señalado, la simplicidad de esta estrategia colisiona con dos grandes realidades: la primera es que todos los insumos químicos necesarios para la producción de Cocaína son sustituibles (con excepción del Ácido Clorhídrico el cual puede ser obtenido en laboratorios rústicos) y la segunda es que todos y cada uno de los Insumos Químicos, sustitutos o no, son también necesarios en la industria lícita.

En ese sentido, el control administrativo de estos productos debe no sólo asegurar y garantizar su disponibilidad para el uso industrial lícito, sino también impedir su acceso en la producción ilícita de drogas.

Antezana Rivera (2011) señala que:

El uso de los insumos químicos, igual que el de la hoja de coca, está entre dos aguas: el legal y el delictivo. Ambas aguas no corren en paralelo, sino se entrelazan y se superponen. Vale decir, el narcotráfico - para producir cocaína - se abastece de los insumos químicos del mercado legal y luego genera una cadena ilegal de suministro de esos productos hasta las zonas donde se produce la droga.

Ello indica que el comercio ilegal de Insumos Químicos forma parte de la estructura del narcotráfico. Es decir, el accionar del narcotráfico está íntimamente unido al desvío de Insumos Químicos desde el mercado legal de esos productos. (p. 156)

En ese orden de ideas y en concordancia con la legislación internacional y regional, el Perú ha venido controlando el comercio de Insumos Químicos que se utilizan en la producción ilícita de drogas (básicamente cocaínicas) desde los años 70 con la emisión del Decreto Ley N 22095 (del 21.02.1978). Posteriormente, el Decreto Supremo $N^{\circ}$ 001-99-IN estableció los procedimientos para la detección de insumos químicos utilizados en las drogas. En julio de 2004 se emitió la Ley $N^{\circ} 28305$ referida al "Control de insumos químicos y productos fiscalizados", reglamentada por el Decreto Supremo $\mathrm{N}^{\circ}$. 053-2005-PCM que establecía el control y fiscalización de 27 Insumos 
Químicos, sus derivados y mezclas, desde su producción al país hasta el destino final, a cargo del Ministerio de la Producción; y finalmente, a través del Decreto Legislativo $\mathrm{N}^{\circ} .1126$ se encargó esta función a la SUNAT.

Este último dispositivo legal establece, entre otros, que ante la detección de determinados supuestos que se detallarán más adelante, procede la incautación de los insumos químicos y del medio de transporte en el cual se trasladaban éstos. La principal consecuencia de esta figura es que el bien incautado pasa a ser propiedad del Estado, produciéndose, por efecto de la ley, una desposesión de parte del patrimonio del Usuario.

Pese a que durante los últimos años, la incautación de insumos químicos se ha ido incrementando, aún es insuficiente frente a los volúmenes que son desviados al narcotráfico. Según datos proporcionados por la Dirección Ejecutiva Antidrogas de la Policía Nacional del Perú - DIRANDRO, el año 2011 la producción de drogas cocaínicas en el país debió requerir alrededor de 36,000 TM de Insumos Químicos, de los cuales se incautaron 1,053 TM, es decir, sólo el 3\% (DEVIDA, 2014, p. 76).

De otro lado, de acuerdo a información de la Gerencia de Fiscalización de Bienes Fiscalizados de la SUNAT, a partir del año 2013 se habrían producido incautaciones, comisos e inmovilizaciones de importantes sumas de Insumos Químicos, tal como se desprende del cuadro siguiente:

Figura 0. 1

Comisos, Incautaciones e Inmovilizaciones 2000-2015

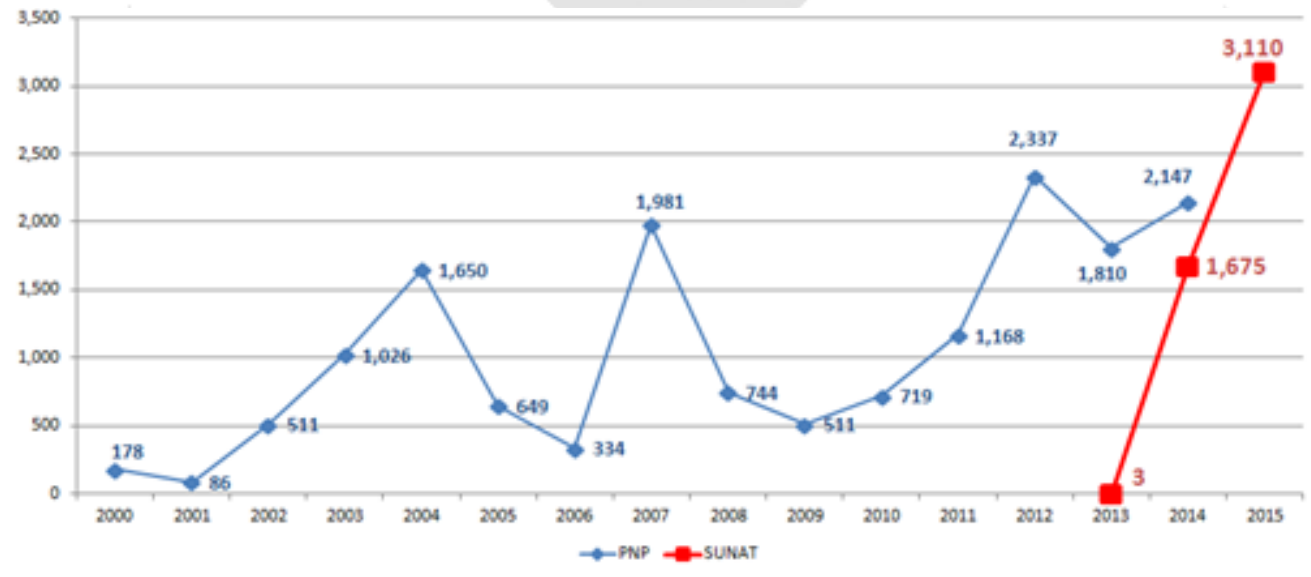

Fuente: Portal Web Policia Nacional del Perú - hatps://wwwi.gng.gob pe/anwaria.html / Registro documentario GFeF - SUNAT

Sin embargo, si consideramos que la producción de drogas no ha variado, estos montos únicamente representan el $4.65 \%$ y el $8.64 \%$ de lo que se desvía hacia las zonas 
productoras, de donde se desprende que todavía existe un amplio margen sobre el cual la SUNAT debe trabajar e implementar mecanismos de control y ejecutar incautaciones.

Ahora bien, ¿qué implica la desposesión de los bienes incautados? ¿Cuáles son los efectos tributarios, respecto del Impuesto a la Renta e Impuesto General a la Ventas de este retiro de los bienes del patrimonio del Usuario?

Esas y algunas otras consideramos son las que pretendemos dilucidar a lo largo del presente trabajo.

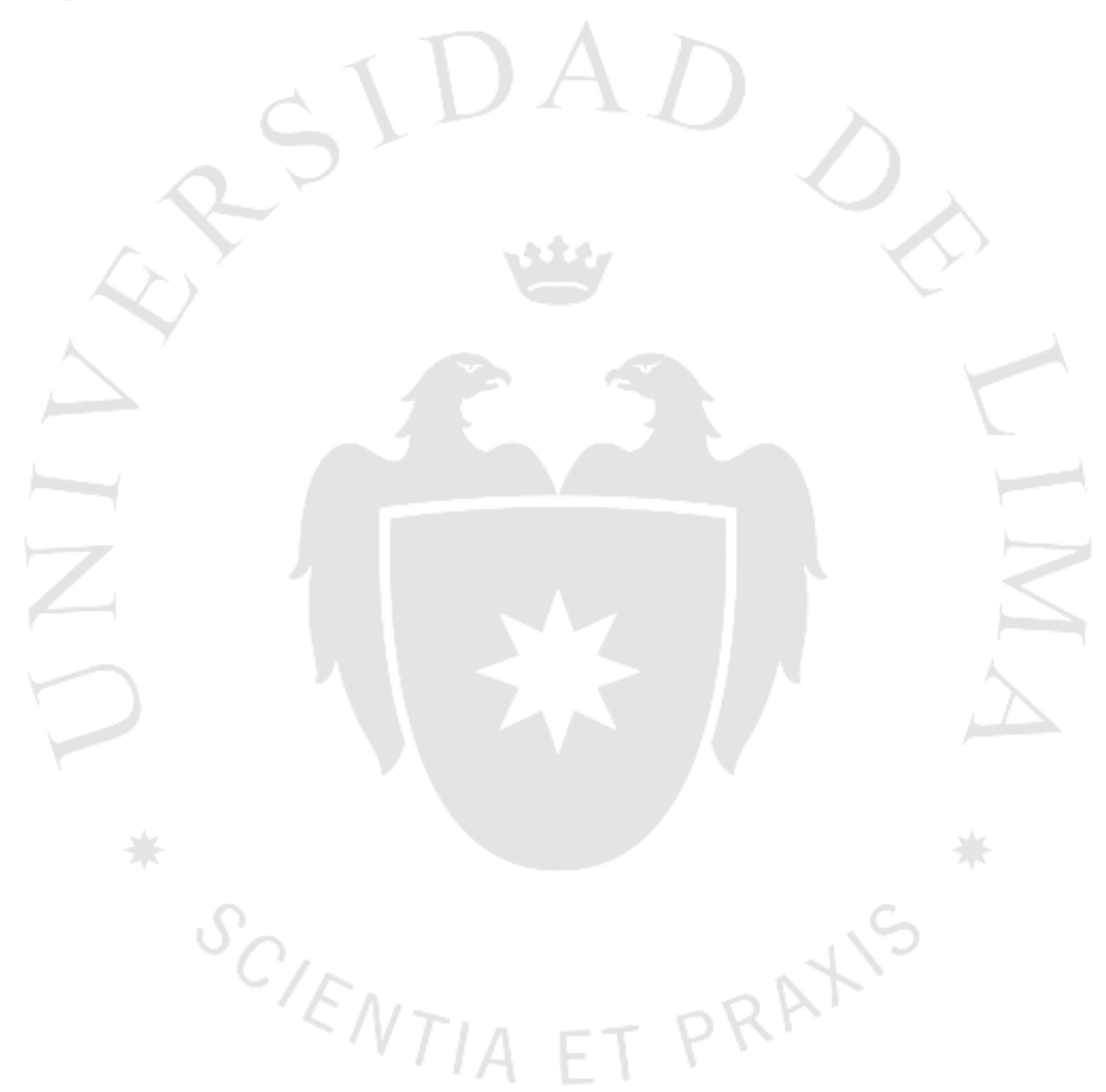




\section{CAPÍTULO I: MARCO CONCEPTUAL}

\subsection{Marco normativo}

La Convención de las Naciones Unidas contra el Tráfico Ilícito de Estupefacientes y Sustancias Sicotrópicas (Viena, 1988), aprobada por Resolución Legislativa N 25352 del 22 de noviembre de 1991, establece, entre otros, que cada una de las Partes adoptará las medidas que sean necesarias para tipificar como delitos penales en su derecho interno, cuando se cometan intencionalmente las figuras siguientes:

- La fabricación, el transporte o la distribución de equipos, materiales o de las sustancias enumeradas, a sabiendas de que van a utilizarse en el cultivo, la producción o la fabricación ilícita de estupefacientes o sustancias sicotrópicas o para dichos fines.

- La posesión de equipos o materiales o sustancias enumeradas a sabiendas de que se utilizan o se habrán de utilizar en el cultivo, la producción o la fabricación ilícita de estupefacientes o sustancias sicotrópica o para tales fines.

Por su parte, el numeral 1 del artículo $12^{\circ}$ de la referida Convención señala que las Partes adoptarán las medidas que estimen adecuadas para evitar la desviación de las sustancias enumeradas utilizadas en la fabricación ilícita de estupefacientes o sustancias sicotrópicas, y cooperarán entre ellas con ese fin.

El numeral $8^{\circ}$ del mismo artículo y cuerpo legal dispone que se adoptarán las medidas que estimen oportunas para vigilar la fabricación y la distribución de sustancias enumeradas que se realicen dentro de su territorio. Con este fin las Partes podrán:

- Controlar a todas las personas y empresas que se dediquen a la fabricación o la distribución de tales sustancias.

- Controlar bajo licencia el establecimiento y los locales en que se realicen las mencionadas fabricación o distribución.

- Exigir que los licenciatarios obtengan la autorización para realizar las mencionadas operaciones.

- Impedir la acumulación en posesión de fabricantes y distribuidores de cantidades de esas sustancias que excedan de las que se requieran el 
desempeño normal de las actividades comerciales y las condiciones prevalecientes en el mercado.

El numeral $9^{\circ}$ señala que cada una de las Partes dispondrá la incautación de cualquiera de las sustancia enumeradas hay pruebas suficientes de que se ha de utilizar para la fabricación ilícita de estupefacientes o sustancias sicotrópicas.

Por su parte, el Convenio Rodrigo Lara Bonilla suscrito entre los países miembros del Acuerdo de Cartagena, sobre Cooperación para la Prevención del Uso Indebido y la Represión del Tráfico Ilícito de Estupefacientes y Sustancias Psicotrópicas”, aprobado por Resolución Legislativa $N^{\circ} 24816$, vigente desde el 21 de marzo de 1991, establece que en el caso de las drogas de origen sintético y aquellas de origen natural, los programas de reducción de la oferta deben enfocarse en prevenir la fabricación ilícita de este tipo de drogas, incluyendo la adopción de controles nacionales apropiados de precursores, el control de comercio internacional de precursores químicos, de acuerdo con el marco establecido en las Convenciones sobre Drogas de las Naciones Unidas y la aplicación de la ley para prevenir la fabricación y el tráfico ilícito de este tipo de sustancias.

De otro lado, el Numeral 34 de la Estrategia Hemisférica sobre Drogas, aprobada por la Comisión Interamericana para el Control del Abuso de Drogas (CICAD) en su cuadragésimo séptimo período ordinario de sesiones - Mayo de 2010 establece que:

Se deben fortalecer los marcos normativos e institucionales de fiscalización efectiva de precursores y sustancias químicas esenciales para evitar su desvío a actividades ilícitas. Teniendo en cuenta la utilización de nuevas sustancias químicas para la fabricación ilícita de drogas, se actualizarán periódicamente las listas de sustancias sujetas a fiscalización, cuando resulte pertinente.

De igual manera, el Plan de Acción Hemisférico sobre Drogas 2011-2015 adoptado por la referida Comisión Interamericana para el Control del Abuso de Drogas (CICAD) en su cuadragésimo noveno período ordinario de sesiones, aprobado el 4 de mayo de 2011, señala como Objetivo $\mathrm{N}^{\circ} 2$ de Medidas de Control el "Adoptar o fortalecer las medidas de fiscalización con el fin de prevenir el desvío de sustancias químicas controladas hacia actividades ilícitas" proponiendo, entre otras, las acciones siguientes:

- Revisar la normativa y las medidas de control existentes para prevenir el desvío de sustancias químicas controladas hacia canales ilícitos. 
- Evaluar los resultados alcanzados a través de la implementación de medidas y programas orientados a prevenir el desvío de sustancias químicas controladas hacia actividades ilícitas.

- Promover la coordinación interinstitucional entre todas las dependencias involucradas en el control de sustancias químicas, así como la promoción de la participación del sector privado.

- Promover o fortalecer metodologías para análisis de riesgo de desvío en operaciones de comercio exterior.

- Promover, cuando corresponda, la realización de estimaciones sobre necesidades legítimas de sustancias químicas controladas para prevenir posibles desvíos.

Por su parte, el numeral 16 de la Declaración de Antigua - Guatemala, "Por una política integral frente al problema mundial de las drogas en las Américas”, señala:

Que instan a los países productores, exportadores, importadores y de tránsito de sustancias químicas y precursores que se utilizan en la fabricación ilícita de estupefacientes y sustancias sicotrópicas, a reforzar, en cooperación con el sector privado, las medidas de control de la producción, distribución y comercialización interna e internacional de sustancias químicas y precursores a fin de evitar su desvío hacia actividades ilícitas, así como a fomentar la cooperación internacional y alianzas estratégicas entre los ámbitos público y privado.

En cuanto a la legislación andina, la Decisión 505 aprueba el Plan Andino de Cooperación para la Lucha contra las Drogas Ilícitas y Delitos Conexos, cuyo programa de acción establece, entre otros:

- Reforzar los controles a las empresas que producen, utilizan y/o comercializan las sustancias químicas controladas con el fin de evitar su desvío hacia la producción de drogas ilícitas.

- Reforzar los dispositivos que permitan controlar la producción ilícita y el contrabando de sustancias químicas controladas y establecer y/o fortalecer los mecanismos de control al transporte y desvío de sustancias químicas en el territorio nacional.

Por su parte, la Decisión 602 - Norma Andina para el Control de Sustancias Químicas que se utilizan en la Fabricación de Ilícitos, establece el control y vigilancia de la importación, exportación, transporte y cualquier otro tipo de transacción a nivel andino 
y desde terceros países, de las sustancias químicas comprendidas en la Lista Única Comunitaria Básica, identificadas en el Anexo I, que se utilizan con frecuencia en la producción, fabricación, preparación o extracción ilícita de estupefacientes, sustancias psicotrópicas, en particular de cocaína y heroína.

Finalmente, dentro de la legislación nacional, el artículo $18^{\circ}$ de la Constitución Política dispone que el Estado combate y sanciona el tráfico ilícito de drogas. Asimismo regula el uso de los tóxicos sociales.

Mediante el Decreto Legislativo $N^{\circ}$. 1126 se establecieron medidas de control en los insumos químicos y productos fiscalizados, maquinarias y equipos utilizados para la elaboración de drogas ilícitas, indicando que corresponde a la SUNAT implementar, desarrollar y mantener el Registro, así como ejercer el control y fiscalización de los Bienes Fiscalizados. Dicho control incluye, entre otros, el ingreso, permanencia, transporte o traslado y salida de bienes fiscalizados, así como la distribución, hacia y desde el territorio aduanero y en el territorio nacional, sin perjuicio de las competencias de otras entidades del Estado, de conformidad con la legislación vigente.

La SUNAT, igualmente, se encarga, entre otros, del control y fiscalización de la documentación que contenga la información sobre el empleo de los Bienes Fiscalizados y de aplicar sanciones administrativas

La Estrategia Nacional de Lucha contra las Drogas 2012-2016 se aprobó mediante Acuerdo Directivo de DEVIDA N . 03-DV-Consejo Directivo-2015 (de fecha 31 de agosto de 2015) estableciéndose, entre otros, la implementación del programa "Interdicción y Sanción" cuyo Objetivo Específico $\mathrm{N}^{\circ} 2$ es el de “incrementar el decomiso de insumos y productos químicos fiscalizados, optimizando su control”.

Entre las líneas de acción de este Objetivo Específico se encuentra la de "Incrementar las operaciones de fiscalización, incautación y decomiso" de insumos químicos y productos desviados para la elaboración de drogas ilícitas", estableciendo como meta país para el año 2016, el decomiso, incautación y similares de 3,500 TM.

\footnotetext{
${ }^{1}$ No hemos encontrado ninguna definición de los términos Comiso o Incautación al amparo de las normas que regulan la Estrategia Nacional de Lucha contra las Drogas. Muy por el contrario, estos términos se usan indistintamente en los artículos consultados. Sin embargo, para efecto de la actuación de SUNAT se entiende que la Incautación se realiza al amparo del Decreto Legislativo $\mathrm{N}^{\circ} 1126$ y origina la desposesión de los bienes; mientras que el Comiso se desarrolla al amparo de las normas tributarias.
} 


\subsection{Incautaciones}

La definición contenida en el numeral 14 del artículo $2^{\circ}$ del Decreto Supremo $N^{\circ}$. 0442013-EF señala que la incautación es la acción mediante la cual se retira del dominio del Usuario los Bienes Fiscalizados o los medios de transporte utilizados para su traslado, de acuerdo a lo dispuesto en la Ley y el Reglamento.

Por su parte, el artículo $39^{\circ}$ del Decreto Legislativo $\mathrm{N}^{\circ} .1126$ establece que los bienes fiscalizados, así como los medios de transporte incautados por la SUNAT, son de titularidad del Estado y la SUNAT actúa en representación de éste ${ }^{2}$ para efecto de las acciones de disposición que el referido Decreto Legislativo le faculta.

La SUNAT podrá disponer el almacenamiento de los Bienes Fiscalizados y los medios de transporte incautados, así como su venta, remate, donación, destrucción, neutralización, destino a entidades del Sector Público, o su entrega al sector competente. Para el caso de medios de transporte incautados, la venta procederá una vez culminado el proceso judicial correspondiente.

La disposición de los Bienes Fiscalizados y la donación o destino de los medios de transporte se efectuará aun cuando se encuentre en investigación fiscal o el proceso judicial el curso, dando cuenta al fiscal o juez penal que conoce la causa.

Si por resolución judicial con calidad de cosa juzgada o por resolución o disposición del Ministerio Público firme, consentida y confirmada por el superior jerárquico, se dispone la devolución de los Bienes Fiscalizados y medios de transporte, se procederá a su devolución o la restitución de su valor al propietario.

Como puede apreciarse, la incautación, para efectos del control de Insumos Químicos, implica la pérdida de dominio por parte del Usuario a favor del Estado, de manera inmediata y hasta irreversible $\mathrm{e}^{3}$ sin otorgarle el derecho de poder impugnar dicha decisión de manera previa y administrativa.

En efecto, por muy drástica que pueda parecer esta medida, debe su razón al bien tutelado que protege. Debemos mencionar que el Decreto Legislativo $N^{\circ} 1126$ fue emitido al amparo de las facultades delegadas en el Poder Ejecutivo a través de la Ley $\mathrm{N}^{\circ} .29915$ referida al fortalecimiento y reforma institucional del sector interior y de defensa nacional, como parte de la estrategia de seguridad y defensa nacional.

\footnotetext{
Esta situación también es referida en el artículo $26^{\circ}$ del Decreto Legislativo $\mathrm{N}^{\circ} .1126$.

En aquellos casos en que a pesar de mediar orden de la autoridad, la SUNAT no podrá cumplir el mandato porque ya dispuso de los bienes.
} 
Ahora bien, el referido Decreto Legislativo dispone que procede la incautación en los supuestos siguientes:

- Cuando se pretenda ingresar al país bienes fiscalizados sin contar la correspondiente autorización de importación (artículo $23^{\circ}$ ), o cuando ésta ha sido cancelada ${ }^{4}$.

- Cuando se trasladan bienes fiscalizados en un medio de transporte no autorizado (artículo $26^{\circ}$ ).

- Cuando se trasladan bienes fiscalizados sin la documentación pertinente ${ }^{5}$ (artículo $26^{\circ}$ ).

- Cuando se detecte el transporte ilegal de Insumos Químicos ${ }^{6}$ (artículo $31^{\circ}$ ).

- Cuando se detecte la presunta comisión del delito de Comercio Clandestino ${ }^{7}$ (artículo $\left.32^{\circ}\right)$.

- Cuando se detecte la presunta comisión del delito de Tráfico de Insumos Químicos ${ }^{8}$ (artículo $32^{\circ}$ ).

De manera adicional, el artículo $47^{\circ}$ del Decreto Legislativo 1126 prevé la aplicación de la incautación como sanción ante el incumplimiento de las obligaciones que corresponden al Usuario, independientemente de las acciones de naturaleza civil o penal a que hubiere lugar.

En ese orden de ideas, la Tabla de Infracciones y Sanciones aprobada por el Decreto Supremo N 010-2015-EF establece que la incautación se aplicará cuando:

- Se realizan actividades fiscalizadas sin contar con inscripción vigente en el Registro.

- Se realizan actividades fiscalizadas no inscritas en el Registro.

4 De acuerdo a la precisión contenida en el Decreto Supremo N ${ }^{\circ}$. 044-2013-EF.

5 Si bien la norma no establece de qué documentos se trata, debe entenderse que se refiere a los documentos que sustentan el traslado de bienes: La guía de remisión o la factura, en los casos que corresponda.

6 Será considerado transporte ilegal todo aquel traslado de bienes fiscalizados que no utilice la Ruta Fiscal aplicable o que no se someta a los controles que no tenga la documentación exigida.

$7 \quad$ Tipificado en el artículo $272^{\circ}$ del Código Penal, que establece, que será reprimido con pena privativa de libertad el que se dedique, entre otros, a una actividad comercial sujeta a autorización sin haber cumplido los requisitos que exijan las leyes o reglamentos.

8 Tipificado en el artículo 296-B del Código Penal que señala que el que importa, fabrica, produce, elabora, transforma, almacena, posee, transporta, adquiere, vende o de cualquier modo transfiere insumos químicos o productos, sin contar con las autorizaciones o certificaciones respectivas, o contando con ellas hace uso indebido de las mismas, con el objeto de destinarlos a la producción, extracción o preparación ilícita de drogas, será reprimido con pena privativa de libertad no menor de 5 ni mayor de 10 años y con 60 a 120 días multa. 
- Se realizan actividades fiscalizadas con bienes fiscalizados no inscritos en el registro.

- Se producen o fabrican bienes fiscalizados alterando las especificaciones contenidas en el informe técnico o cuadro insumo-producto o bienes fiscalizados no especificados en dichos documentos.

- Se transportan bienes fiscalizados en un medio de transporte no inscrito en el registro.

- Se remiten bienes fiscalizados en un medio de transporte no inscrito en el registro.

- Se comercializan bienes fiscalizados excediendo los límites de volumen o cantidad en las zonas geográficas sujetas a régimen especial.

- Se realizan actividades fiscalizadas con bienes fiscalizados excediendo las cantidades indicadas en el registro.

- Se comercializan bienes fiscalizados para uso doméstico o artesanal en presentaciones y/o concentraciones y/o volúmenes y/o pesos no autorizados.

- Se comercializan bienes fiscalizados sin cumplir con las especificaciones detalladas en el rotulado y/o etiquetas sobre denominación, concentración, peso o volumen.

- Se ingresan o sacan bienes fiscalizados hacia o desde el territorio nacional sin contar con autorización.

- Se transportan bienes fiscalizados sin utilizar la ruta fiscal.

- Se transportan bienes fiscalizados sin guía de remisión u otro documento previsto por las normas para sustentar su traslado, o con documentos que no reúnan los requisitos y características para ser considerados guías de remisión y/u otro documento que carezca de validez.

- No se cuenta, en el caso de bienes fiscalizados que se transporten en contenedores, cisternas o similares, con los medios de seguridad que garanticen su inviolabilidad.

- No se cuenta, en el caso de bienes fiscalizados que se transporten en contenedores, cisternas o similares, con el rotulado o etiquetado respectivo según las normas de la materia.

- Se impide la toma de muestras o la toma de inventarios de bienes fiscalizados o de bienes que presumiblemente sean bienes fiscalizados. 
Teniendo lo señalado hasta este momento, es necesario, para los fines del presente trabajo, tener en claro la naturaleza jurídica de la incautación prevista en las normas que regulan el control de Insumos Químicos:

a) La incautación como medida expropiatoria:

El Artículo $70^{\circ}$ de la Constitución Política establece que el derecho de propiedad es inviolable. El Estado lo garantiza. Se ejerce en armonía con el bien común y dentro de los límites de ley. A nadie puede privarse de su propiedad, sino exclusivamente, por causa de seguridad nacional o necesidad pública, declarada por ley, y previo pago en efectivo de indemnización justipreciada que incluya compensación por el eventual perjuicio. Hay acción judicial ante el Poder Judicial para contestar el valor de la propiedad que el Estado haya señalado en el procedimiento expropiatorio.

Mediante Decreto Legislativo Nº 1192 se aprobó la Ley Marco de Adquisición y Expropiación de Inmuebles, Transferencia de Inmuebles de Propiedad del Estado, Liberación de Interferencias y otras medidas para la ejecución de obras de infraestructura.

En ella se define a la expropiación como la transferencia forzosa del derecho de propiedad privada sustentada en causa de seguridad nacional o necesidad pública, autorizada únicamente por ley expresa del Congreso de la República a favor del Estado, a iniciativa del Gobierno Nacional, Gobiernos Regionales o Gobiernos Locales y previo pago en efectivo de la indemnización justipreciada que incluya compensación por el eventual perjuicio.

Como se puede apreciar, fluye de los párrafos precedentes que si bien tanto la incautación prevista en el Decreto Legislativo $\mathrm{N}^{\circ} .1126$ y la expropiación se sustentan en causas de seguridad nacional, existen entre ambas figuras grandes diferencia, entre las que podemos mencionar las siguientes:

Figura 1. 1

Diferencias entre incautación y expropiación

\section{Incautación}

- Referida a bienes muebles.

\section{Expropiación}

- Referida a bienes inmuebles. 
- No requiere ley previa.

- No media pago de indemnización alguna.

- No necesariamente existe perjuicio del Usuario.
- Requiere ley previa.

- Se efectúa previo pago de indemnización justipreciada.

- Siempre existe perjuicio al Usuario, el cual será compensado.

Puede entonces concluirse que la incautación y la expropiación son figuras distintas entre sí y por lo tanto requieren tratamiento diferente.

b) La incautación como medida sancionatoria

De acuerdo al Diccionario de la Real Academia de la Lengua Española, la palabra sanción es la pena que una ley o reglamento establece para sus infractores, o es el mal dimanado de una culpa o yerro y que es como su castigo o pena (Real Academia Española, 2014, $23^{\circ}$ ed.)

Si bien estas definiciones parecieran encajar dentro del concepto que parece fluir del concepto de incautación previsto en el Decreto Legislativo $\mathrm{N}^{\circ}$. 1126, normas modificatorias y reglamentarias, debemos tener en cuenta que la Ley del Procedimiento Administrativo General regula la facultad que se atribuye a cualquiera de las entidades para establecer infracciones administrativas y las consecuentes sanciones a los administrados; estableciendo, entre otros, la obligatoriedad de realizar el procedimiento administrativo sancionador, al final del cual recién se podría interponer la medida sancionatoria ${ }^{9}$.

En ese orden de ideas, en principio, esta diferencia lleva a concluir que la incautación prevista en los artículos $23^{\circ}, 26^{\circ}$ y $32^{\circ}$ del Decreto Legislativo $\mathrm{N}^{\circ}$. 1126, dada su aplicación inmediata y sin previo proceso administrativo, no constituye la aplicación de una medida sancionatoria, de conformidad con las normas del procedimiento administrativo general.

Situación distinta se presenta en el caso de las incautaciones previstas en el Decreto Supremo $N^{\circ}$ 010-2015-EF que aprueba la Tabla de Infracciones y Sanciones por el incumplimiento de las obligaciones contenidas en el Decreto Legislativo $\mathrm{N}^{\circ}$. 1126 y regula el Procedimiento Administrativo Sancionador respectivo a cargo de la SUNAT, que si constituyen medidas sancionatorias aplicables luego de la conclusión del procedimiento administrativo sancionador previsto en la Ley $\mathrm{N}^{\circ} 27444$.

\footnotetext{
${ }^{9}$ Salvo que existan procedimientos especiales establecidos en leyes especiales, las que deberán observar necesariamente los principios de la potestad sancionadora administrativa, así como la estructura y garantías previstas para el procedimiento administrativo sancionador.
} 
Podemos entonces concluir que, respecto de la incautación, existen dos subcategorías perfectamente diferenciadas entre si y de naturaleza distinta.

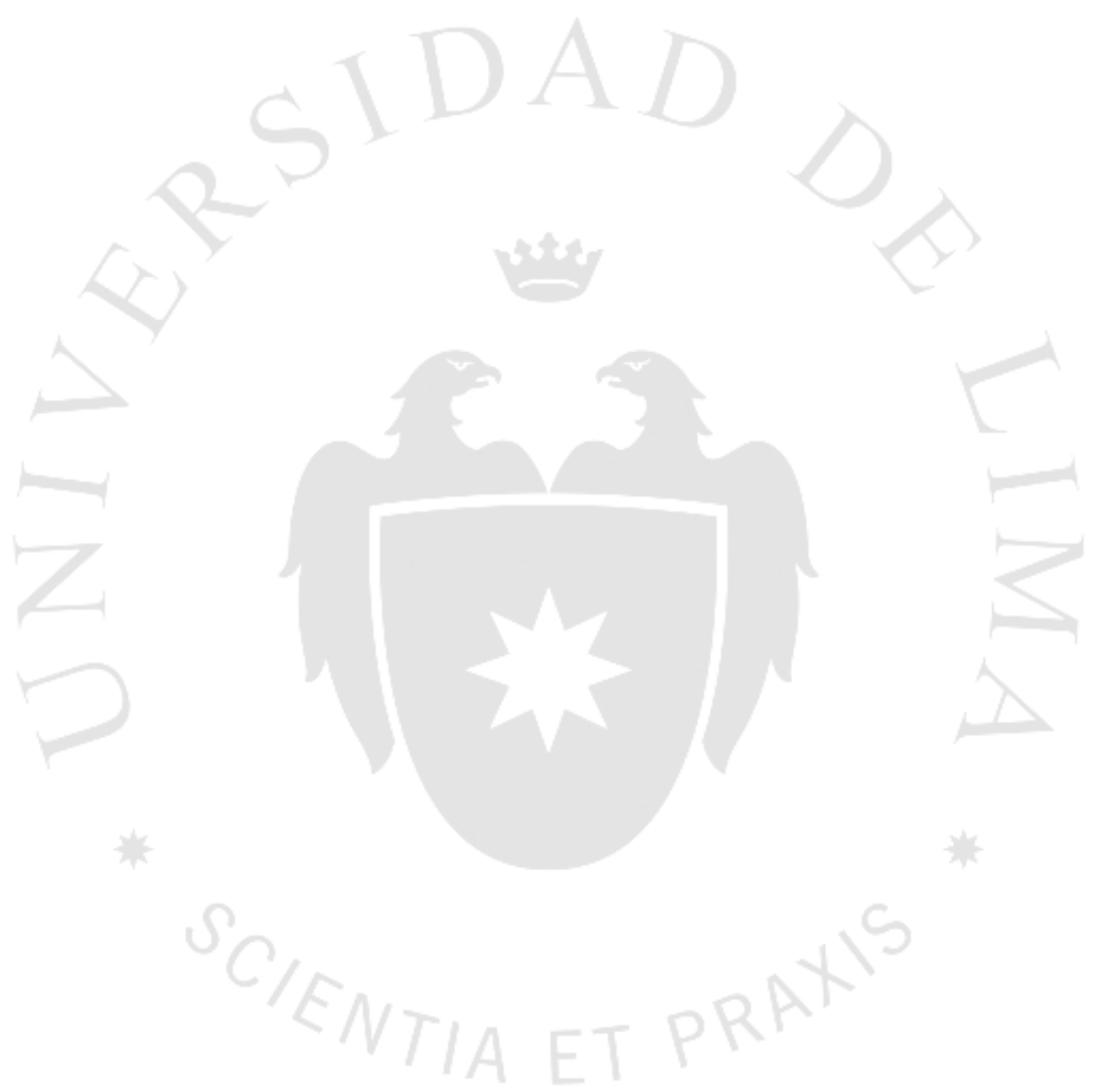




\section{CAPÍTULO II: REGIMEN TRIBUTARIO APLICABLE}

Hemos visto hasta ahora que los Usuarios de Insumos Químicos pueden enfrentar en cualquier momento la desposesión de bienes que constituyen su patrimonio.

Puede suceder también que la medida de incautación se aplique sobre bienes que no pertenecen al Usuario. Ello sucede cuando, por ejemplo, los Insumos Químicos se trasportan a través de una empresa de servicios y, en aplicación del artículo $32^{\circ}$ del Decreto Legislativo $\mathrm{N}^{\circ} .1126$ proceda también a la incautación del medio de transporte, o cuando el vehículo está siendo adquirido a través del sistema de arrendamiento financiero o ha sido alquilado a tercera persona.

A lo largo del presente capítulo pretendemos explicar las consecuencias tributarias que puede acarrea para el Usuario-contribuyente y/o terceros involucrados en una medida de incautación aplicada por la SUNAT al amparo de las normas que regular en control y fiscalización de Insumos Químicos y Bienes Fiscalizados.

Para ello también debemos precisar que los bienes incautados pueden haber sido adquiridos de manera regular con el producto de actividades lícitas, o muy por el contrario, ser adquisiciones que pretenden ingresar dinero proveniente de actividades ilícitas. Esta diferenciación se torna importante en el presente trabajo porque, como veremos más adelante, las consecuencias entre una y otra situación son distintas.

\subsection{Impuesto a la Renta}

La legislación nacional establece que las rentas provenientes del comercio y la industria constituyen renta de tercera categoría, entendidas como tales, entre otras, las derivadas de la prestación de servicios comerciales, industriales o de índole similar, como transporte; y en general de cualquier otra actividad que constituye negocio habitual de compra o producción y venta, permuta o disposición de bienes.

No cabe duda entonces que las ganancias producidas por los Usuarios de Insumos Químicos por sus actividades fiscalizadas ${ }^{10}$ constituyen rentas de tercera

10 De acuerdo al artículo $3^{\circ}$ del Decreto Supremo $N^{\circ}$ 044-2013-EF las disposiciones contenidas en el Decreto Legislativo alcanzan a las actividades de producción, fabricación, preparación, envasado, reenvasado, comercialización, transporte, servicio de transporte, almacenamiento, servicio de almacenamiento, transformación, utilización o prestación de servicios en el territorio nacional, 
categoría, por las cuales deberían, en principio, pagarse el impuesto correspondiente de conformidad con las normas establecidas.

\subsubsection{Bienes adquiridos con el producto de actividades lícitas.}

Se trata de bienes adquiridos a través de fuentes de financiamiento lícitas pero que por una u otra razón han sido destinados a operaciones irregulares ${ }^{11}$ vinculadas a insumos químicos.

\subsubsection{Incautaciones efectuadas ante la existencia de un indicio de presunto delito}

\section{de Tráfico Ilícito de Drogas.}

Pongamos el ejemplo de la empresa A que vende a la empresa B la cantidad de 1000 litros de Acetona (en distintas presentaciones de uso no doméstico) a un precio de $\mathrm{S} / 350,000$ puestos en su local ubicado en Pisco. A contrata a la empresa " $\mathrm{M}$ Transportes" para que realice el traslado del producto al costo de S/10,000.

Todas las adquisiciones de los bienes involucrados (la acetona y el vehículo de transporte) han sido efectuadas de manera lícita. Es decir, hasta el momento de la incautación esos productos no tenían ningún problema con su ingreso al mercado.

No obstante ello, en el puesto de control de Pucusana (es decir, también se seguía la ruta fiscal establecida para los traslados hacia el sur del país) se detecta que la acetona se encontraba acondicionada dentro de sacos rellenos de papa, lo que hace presumir que se trataría de una operación de desvío de insumos químicos, por lo que, al amparo del artículo $32^{\circ}$ del Decreto Legislativo $\mathrm{N}^{\circ}$. 1126, el personal de SUNAT procede a incautar la acetona y el medio de transporte.

Para analizar las consecuencias ${ }^{12}$ de esta acción administrativa interpuesta por la SUNAT debemos tener en claro que existen dos contratos civiles independientes y

regímenes y operaciones aduaneras para el ingreso o salida del país referidas a los Bienes Fiscalizados.

11 Téngase en cuenta que nos referidos a operaciones irregulares toda vez que únicamente el Ministerio Público es la autoridad competente para determinar, luego de una investigación, si se trata de un delito penal o no; y será la autoridad judicial la de definitivamente establezca esta situación. De otro lado, si se estuviera frente a un delito de manera indubitable, sería de aplicación el artículo $1140^{\circ}$ del Código Civil que establece que el deudor no está eximido de pagar el valor del bien cierto, aunque éste se haya perdido sin culpa, cuando la obligación proviene del delito o falta, salvo que se haya constituido en mora al acreedor.

12 El análisis efectuado no toma en cuenta las responsabilidades penales que pudieran derivarse de la confirmación del hecho delictivo. 
diferenciables entre sí: el contrato de compra venta suscrito entre A y B; y el contrato de transporte suscrito entre A y la empresa de Transportes.

Veamos entonces, las implicancias en la esfera económica de cada uno de los involucrados en ambos contratos:

\section{a) Tratándose del contrato de compra venta.}

Siendo verdad que el objeto contenido en la obligación de dar (acetona) es, en principio, un bien incierto, debe tenerse presente que una efectuada la elección, este se convierte en bien cierto ${ }^{13}$, debiendo entonces aplicarse la teoría del riesgo prevista en el artículo $1138^{\circ}$ del Código Civil ${ }^{14}$.

\section{a.1) Si el bien se pierde por culpa del vendedor (deudor de la obligación de} dar la acetona).

$\mathrm{Su}$ obligación queda resuelta, pero el acreedor deja de estar obligado a su contraprestación, si la hubiere, y el deudor queda sujeto al pago de la correspondiente indemnización (numeral 1 del artículo $1138^{\circ}$ ).

- Consecuencias para el vendedor:

Como puede apreciarse, no percibirá, por esta transacción, pago alguno. Muy por el contrario, su esfera económica se verá disminuida por los hechos siguientes:

Pérdida de los insumos químicos incautados:

El artículo $37^{\circ}$ de la Ley del Impuesto a la Renta establece, entre otros, que pueden deducirse de la renta bruta los gastos necesarios para producirla y mantener su fuente. El inciso d) de dicho artículo señala que son deducibles las pérdidas extraordinarias sufridas por caso fortuito o fuerza mayor en los bienes productores de renta gravada o por delitos cometidos en perjuicio del contribuyente por sus dependientes o terceros, en la parte que tales pérdidas no resulten cubiertas por indemnizaciones o seguros y siempre que se haya probado judicialmente el hecho

13 El artículo $1147^{\circ}$ del Código Civil establece que practicada la elección (de los bienes inciertos), se aplican las reglas establecidas sobre obligaciones de dar bienes ciertos.

14 De igual manera, debe considerarse que el artículo $1432^{\circ}$ del Código Civil establece reglas similares para los casos de resolución de contratos por culpa de las partes. 
delictuoso o que se acredite que es inútil ejercitar la acción judicial correspondiente.

En el caso bajo análisis, entonces, habría que determinar si la situación que ocasionó la incautación de los insumos químicos fue consecuencia de una responsabilidad penal imputable al trabajador del vendedor, en cuyo caso (en la medida que no exista seguro que la cubra) una vez finalizado el proceso penal que determine esta responsabilidad, el usuario/contribuyente podría deducir la pérdida de la acetona.

Caso contrario no procederá la deducción por cuanto se ha quebrado el principio de causalidad.

Pago de la indemnización que debe efectuar a las otras partes involucradas que hubieran sufrido algún daño:

El artículo $44^{\circ}$ de la Ley del Impuesto a la Renta establece como concepto no deducible, las multas, recargos, intereses moratorios previstos en el Código Tributario, y en general las sanciones aplicadas por el Sector Público Nacional.

En el caso bajo comentario no corresponde a ninguno de los conceptos señalados por lo que, en principio, consideramos que si podría deducir estos montos como gasto para la efectos de la determinación del Impuesto a la Renta, máxime si, estos montos constituyen renta gravada para quienes lo perciben.

La SUNAT, a través del Informe N 091-2003-SUNAT/2B0000, ha señalado que "en las operaciones de compra-venta que se perfeccionan de acuerdo a los usos y costumbres aceptados en el comercio internacional, las penalidades que el comprador domiciliado en el exterior (importador) impone al vendedor domiciliado en el país (exportador) por el incumplimiento de los términos contractuales, constituyen gasto deducible para la determinación de la renta neta imponible".

El argumento para dicha posición es que "si bien es cierto que entre los gastos deducibles que se mencionan en el artículo $37^{\circ}$ del TUO del IR no se ha incluido a las penalidades, dicha enumeración no es taxativa sino sólo enunciativa. 
Ahora bien, en cuanto a la naturaleza de la cláusula penal contemplada en el Código Civil, la misma es concebida como una relación obligacional destinada a que las partes fijen la reparación para el caso de incumplimiento de la obligación, la cual se pretende sea cumplida en todos sus términos con la estipulación de la cláusula penal.

De lo anterior se desprende una característica esencial de la cláusula penal: su accesoriedad a la obligación principal, en el sentido que aquella está orientada a asegurar el cumplimiento de esta última.

Dado que el supuesto que motiva la consulta, el incumplimiento de los términos de los contratos de compra venta realizados es el hecho que origina el pago de las penalidades, se puede concluir que dicho pago es un gasto vinculado a la producción y mantenimiento de la fuente de la renta gravada, generada en relación con los contratos en los que esas penalidades se entienden pactadas."

Ahora bien, de acuerdo a Osterling Parodi (sin fecha) "la cláusula penal es lvaluación anticipada de los daños y perjuicios por el incumplimiento de la obligación. Su propósito es evitar las intricadas cuestiones que surgen de la valorización de los daños y perjuicios por el juez; esto es evitar la prueba del perjuicio y el arbitrio judicial en su estimación."

En ese orden de ideas, es criterio de la Administración Tributaria aceptar el pago de indemnizaciones por el incumplimiento de obligaciones en la medida en que estén previstas en el contrato suscrito.

- Consecuencias para el comprador:

Esta persona no recibirá los bienes y no efectuará desembolso de dinero alguno, por lo que su esfera patrimonial, en principio, no sufriría modificación alguna. Sin embargo, recibirá el pago de una indemnización por parte del vendedor.

A ese respecto, el inciso b) del artículo $3^{\circ}$ de la Ley del Impuesto a la Renta, así como el inciso f) del artículo $1^{\circ}$ del Reglamento de dicha ley establecen que se encuentran gravadas las indemnizaciones destinadas a reponer, total o parcialmente, un bien del activo de la empresa, en la parte en que exceda del costo computable de ese bien, salvo que sea destinado a la reposición total o parcial de dicho bien, y siempre que la adquisición se haya contratado dentro de 
los 6 meses siguientes a la fecha en que se percibió el monto indemnizatorio y el bien se reponga en un plazo que no exceda de 18 meses contados a partir de la referida percepción ${ }^{15}$.

En el caso bajo comentario, la incautación no ocasionó "perdida" de bien alguno para el adquirente, pero es posible que si le hubiera originado el dejar de percibir alguna renta o ganancia (por ejemplo, si él tenía comprometida una reventa de los bienes incautados), situación que de acuerdo al artículo $1985^{\circ 16}$ del Código Civil debe ser reparada.

En efecto, la teoría de la indemnización establece que los daños patrimoniales se manifiestan en el daño emergente (que abarca las pérdidas sufridas) y el lucro cesante (que abarca todo aquello que se dejó de ganar), concepto este último que abarca la situación descrita del comprador.

En consecuencia, podemos afirmar que la totalidad del monto percibido estará afecto con el Impuesto a la Renta al no existir "reposición de bienes", y porque constituye renta gravada de las empresas, cualquier ganancia o ingreso derivado de operaciones con terceros ${ }^{17}$ de acuerdo a lo establecido en el inciso g) del artículo $1^{\circ}$ del Reglamento de la Ley del Impuesto a la Renta.

- Consecuencias para el transportista (tercero en el contrato de compra venta de insumos químicos, pero involucrado en la incautación debido al medio de transporte):

De acuerdo a la teoría de la indemnización referida líneas arriba, el podrá exigir al vendedor la reparación de los daños ocasionados, consistentes en la pérdida

15 En casos debidamente justificados, la SUNAT autorizará un plazo mayor para la reposición física del bien- Asimismo, está facultada a autorizar, por única vez, en casos debidamente acreditados, un plazo adicional para la contratación de la adquisición del bien (inciso f del artículo $1^{\circ}$ del Reglamento).

16 Que establece que la indemnización comprende las consecuencias que deriven de la acción u omisión generadora del daño, incluyendo el lucro cesante, el daño a la persona y el deño moral, debiendo existir una relación de causalidad adecuada entre el hecho y el daño producido.

17 El inciso g) del artículo $1^{\circ}$ del Reglamento de la Ley del Impuesto a la Renta señala que la ganancia o ingreso derivado de operaciones con terceros, se refiere a la obtenida en el devenir de la actividad de la empresa en sus relaciones con otro particulares, en las que los intervinientes participan en igualdad de condiciones y consienten en el nacimiento de obligaciones. En consecuencia, constituye ganancia o ingreso para la empresa, la proveniente de actividades accidentales, los ingresos eventuales y la proveniente de transferencias a título gratuito que realice un particular a su favor. En estos casos, el adquirente deberá considerar ganancia o ingreso al favor de ingreso al patrimonio. El termino empresa comprende a toda persona o entidad perceptora de rentas de tercera categoría y a las personas o entidades no domiciliadas que realicen actividad empresarial. 
del vehículo (daño emergente) y los gastos que dejaría de irrogarse (lucro cesante).

El primero de los conceptos, podría no estar afecto al Impuesto a la Renta en aplicación del inciso b) del artículo $3^{\circ}$ de la Ley del Impuesto a la Renta citado precedentemente, en la medida que se destine a la reposición del bien (vehículo), que la adquisición se contrate dentro de los 6 meses siguientes a la fecha en que se percibió el monto indemnizatorio, que el bien se reponga en un plazo que no exceda de 18 meses contados a partir de la referida percepción ${ }^{18}$ y que el monto percibido no exceda el costo computable del bien a reponer. En caso no se cumplan todos estos requisitos, la indemnización percibida si deberá estar afecta al Impuesto a la Renta, así como también lo estará la parte que exceda del costo computable.

De igual manera, debe tenerse presente que en aplicación del inciso d) del artículo $37^{\circ}$ de la Ley del Impuesto a la Renta, el percibir la indemnización por daño emergente evita que la pérdida del vehículo pueda ser deducible para efectos de determinar la renta neta.

\section{a.2) Si el bien se pierde por culpa del comprador (acreedor en la obligación}

\section{de dar la acetona.}

La obligación del deudor queda resuelta, y éste conserva el derecho a la contraprestación, si la hubiere (numeral 3 del artículo $1138^{\circ}$ ).

\section{- Consecuencias para el vendedor:}

En este supuesto, si bien los insumos químicos se han perdido, el vendedor recibirá la contraprestación pactada, por lo que su situación patrimonial no sufrirá modificación alguna como consecuencia de la incautación (su situación es igual a la que tendría si no se hubiera producido la incautación).

Sin embargo, somos de la opinión que al haberse roto el sinalagma existente entre las obligaciones de ambas partes contratantes (obligación de dar los bienes/obligación de pagar), la naturaleza del monto entregado ya no es el de "contraprestación" sino que surge como indemnización por la mala

18 En casos debidamente justificados, la SUNAT autorizará un plazo mayor para la reposición física del bien- Asimismo, está facultada a autorizar, por única vez, en casos debidamente acreditados, un plazo adicional para la contratación de la adquisición del bien (inciso f del artículo $1^{\circ}$ del Reglamento). 
actuación del acreedor y que pretende compensarlo no por la pérdida de los bienes (por que el comprador es quien la sufre) sino por el lucro cesante que se le hubiera causado.

En ese orden de ideas, son aplicables a este supuesto las consideraciones expuestas anteriormente, en el sentido que la indemnización se encuentra gravadas con el impuesto a la Renta en la medida que no pretende reponer la pérdida de un bien.

- Consecuencias para el comprador:

No recibirá los bienes pactados y adicionalmente deberá pagar las indemnizaciones que correspondan a todos los involucrados que han sufrido algún daño debido a su actuación.

Pérdida de los insumos químicos incautados:

Tal como se señaló, el inciso d) del artículo $37^{\circ}$ de la Ley del Impuesto a la Renta faculta a deducirse de la renta bruta las pérdidas extraordinarias sufridas por caso fortuito o fuerza mayor en los bienes productores de renta gravada o por delitos cometidos en perjuicio del contribuyente por sus dependientes o terceros, en la parte que no resulten cubiertas por indemnizaciones o seguros y siempre que se haya probado judicialmente el hecho delictuoso o que se acredite que es inútil ejercitar la acción judicial correspondiente.

En consecuencia, si el adquirente puede acreditar que la responsabilidad penal corresponde, por ejemplo, a un trabajador podrá deducir la pérdida de estos bienes una vez finalizado el proceso penal que determine esta responsabilidad.

$\checkmark$ Pago de la indemnización que debe efectuar a las otras parte involucradas que hubieran sufrido algún daño:

Estos montos si podrán ser deducibles para la determinación del Impuesto a la Renta debido a las consideraciones previamente expuestas y que básicamente se refieren a que el pago de este monto debe constar en el contrato celebrado entre las partes. 
- $\quad$ Consecuencias para el transportista:

El análisis de las consecuencias de esta situación en relación al este sujeto no varían respecto de lo que se señaló en el acápite anterior, toda vez que sigue siendo un tercero en el contrato de compra venta de insumos químicos involucrado en la incautación debido a la pérdida del medio de transporte. Situación por la cual podrá exigir el pago de una indemnización que le repare el daño emergente y el lucro cesante.

\section{a.3) Si el bien se pierde por culpa del transportista (tercero en el contrato de compra venta de acetona):}

La obligación del deudor queda resuelta, con pérdida del derecho a la contraprestación (numeral 5 del artículo $1138^{\circ}$ ).

- Consecuencias para el vendedor:

Sufre la pérdida patrimonial correspondiente al valor de la acetona, por lo que podrá iniciar las acciones correspondientes contra el transportista (o tercero responsable) hasta lograr, finalmente, el pago de una indemnización.

$\checkmark \quad$ Pérdida de los insumos químicos incautados:

Al amparo del inciso d) del artículo $37^{\circ}$ de la Ley del Impuesto a la Renta podrá deducir de la renta bruta esta pérdida toda vez que se origina en un delito cometidos en perjuicio del contribuyente por un terceros; salvo que ésta se encuentre cubierta con la indemnización que recibiría o por algún seguros y siempre que culmine el proceso judicial que determine la responsabilidad del transportista.

$\checkmark \quad$ Si percibe indemnización por daño emergente ya no podría deducir el valor de la pérdida de los bienes.

- Consecuencias para el comprador:

Si bien no sufre la pérdida de los insumos químicos, puede haber sufrido algún tipo de daño que sea calificado como lucro cesante y por ello percibir un monto 
indemnizatorio, el mismo que, como ya se explicó anteriormente, está gravado con el Impuesto a la Renta.

- Consecuencias para el transportista:

Si bien se trata de un tercero en la relación contractual existente entre el vendedor y el comprador de la acetona, su situación patrimonial se ve afectada por las situaciones siguientes:

$\checkmark \quad$ Pérdida del medio de transporte:

El inciso d) del artículo $37^{\circ}$ de la Ley del Impuesto a la Renta establece permite la deducción de las pérdidas extraordinarias sufridas en los bienes productores de renta gravada por delitos cometidos en perjuicio del contribuyente por sus dependientes o terceros, en la parte que tales pérdidas no resulten cubiertas por indemnizaciones o seguros y siempre que se haya probado judicialmente el hecho delictuoso o que se acredite que es inútil ejercitar la acción judicial correspondiente.

En ese sentido, corresponderá determinar si la incautación de los insumos químicos fue consecuencia de un accionar no imputable al usuario pero si, por ejemplo, a un trabajador suyo; en cuyo caso (en la medida que no exista seguro que la cubra) una vez finalizado el proceso penal que determine esta responsabilidad, podría deducir la pérdida del vehículo. Caso contrario no procederá la deducción por cuanto se ha quebrado el principio de causalidad.

Pago de la indemnización que debe efectuar a las otras partes involucradas que hubieran sufrido algún daño:

Tal como se ha descrito en este trabajo, el pago de las indemnizaciones si son deducibles para la determinación del Impuesto a la Renta, en la medida que consten expresamente en el contrato suscrito entre las partes.

\section{b) Tratándose del contrato de transporte.}

Al momento de analizar esta situación debemos tener en cuenta algunos aspectos importantes: 
- $\quad$ El contenido de la obligación que surge del contrato es una de hacer (prestar el servicio de traslado); sin embargo, la incautación también tendrá consecuencias en la obligación de la entrega de bienes que fue analizada previamente.

Surge la duda sobre la existencia de una imposibilidad real de cumplir con la prestación pactada por causa de la incautación del vehículo; sin embargo, toda vez que por mucho que pudiera continuarse con la presentación del servicio de traslado, ya no existen bienes que trasladar.

- Independientemente de quien haya contratado el servicio de transporte, nos queda la duda si el transportista puede alegar desconocimiento de la realización de un traslado ilegal o, cuando menos, irregular.

En efecto, cuando menos, él es responsable del acondicionamiento de los bienes en el vehículo, por lo que si éstos se encuentran escondidos o camuflados, como mínimo, será considerado como colaborador de presunto hecho delictivo. Salvo que el propietario de la empresa pueda demostrar que desconocía la actuación irregular del chofer (por ejemplo).

- Dependiendo de quien haya contratado el servicio de transporte, el remitente o el destinatario tendrá la calidad de tercero en el contrato de transporte.

\section{b.1) Si el bien se pierde por culpa del remitente (vendedor de los insumos químicos y acreedor en la obligación del servicio de transporte).}

El artículo $1155^{\circ}$ del Código Civil establece que si la prestación resulta imposible por culpa del acreedor, la obligación del deudor (transportista) queda resuelta, pero éste conserva el derecho a la contraprestación, si la hubiere.

Si el deudor (transportista) obtiene algún beneficio con la resolución de la obligación, su valor se reduce la contraprestación a cargo del acreedor

- Consecuencias para el remitente:

Fluye del párrafo precedente que no recibirá el servicio de transporte contratado pero debe cancelar el monto de la contraprestación pactada, monto que en realidad, consideramos, tiene la naturaleza de 
indemnización (en vista que se habría roto el sinalagma que debe existir entre todas las obligaciones pactadas).

Ahora bien, la indemnización que debe cancelar al transportista está conformada por el daño emergente (pérdida del vehículo) y lucro cesante producido (ganancia dejada de percibir).

- $\quad$ Consecuencias para el transportista:

Dado que la pérdida del vehículo obedece a un accionar de un tercero, podría der deducible de la renta bruta en la medida que no fuera indemnizada.

Si recibe la indemnización (contraprestación) y esta es destinada a la reposición del vehículo dentro de los 6 meses de percibido y no supere el conto computable del bien a reponer no estará afecta al Impuesto a la Renta. En caso contrario si lo estará.

\section{Consecuencias para el destinatario:}

Si bien se trata de una tercera persona en el contrato suscrito entre el remitente y la empresa de transporte, se ve perjudicado por no recibir los bienes de manera oportuna o no recibirlos nunca. Por esta situación bien puede recibir una indemnización por lucro cesante, la misma que estará afecta al Impuesto a la Renta toda vez que no está destinada a la reposición de una bien

\section{b.2) Si el bien se pierde por culpa del transportista (deudor en la obligación del servicio de transporte):}

El artículo $1154^{\circ}$ del Código Civil establece que si la prestación resulta imposible por culpa del deudor, su obligación queda resuelta, pero el acreedor deja de estar obligado a su contraprestación, si la hubiere, sin perjuicio de su derecho de exigirle el pago de la indemnización que corresponda.

- Consecuencias para el remitente: 
El artículo $1150^{\circ}$ del Código Civil establece que el incumplimiento de la obligación de hacer por culpa del deudor, faculta al acreedor a optar por cualquiera de las siguientes medidas:

$\checkmark \quad$ Exigir la ejecución forzada del hecho prometido.

$\checkmark \quad$ Exigir que la prestación sea ejecutada por persona distinta al deudor y por cuenta de éste.

$\checkmark$ Dejar sin efecto la obligación.

Las dos primeras alternativas no son de aplicación en el caso de las incautaciones analizadas toda vez que esta medida también abarcará a los bienes que eran transportados, por lo que ya no existen bienes susceptibles de ser trasladados.

Sin embargo, lo que interesa para efectos del presente trabajo es la disposición contenida en el artículo $1152^{\circ}$ del Código Civil que dispone que en cualquiera de estos casos, el acreedor tiene derecho a exigir el pago de la indemnización que corresponda. Este monto deberá incluir los daños ocasionados por daño emergente (pérdida de los insumos químico) y lucro cesante.

El valor de la pérdida de los bienes podría ser deducida de la renta bruta en la medida que no fuera indemnizada.

De igual manera, la indemnización percibida estará afecta al referido impuesto en la medida que supere al costo computable del bien, o no se cumplan con los requisitos establecidos por la ley para la inafectación de este concepto.

- Consecuencias para el transportista:

Deberá indemnizar al deudor por el lucro cesante que se derive de tal situación $^{19}$, quien deberá pagar Impuesto a la Renta por dicho monto en la medida que sea superior al costo computable de los bienes que repondrá.

Consideramos que igualmente deberá indemnizar al destinatario por el lucro cesante en que incurriría, quien igualmente pagará el Impuesto a la Renta por este monto.

19 Si bien la pérdida de los insumos químicos constituye un daño emergente que también debe ser indemnizado, esta situación ya fue analizada previamente en el rubro referido al contrato de compra venta. 
El pago de estos conceptos, como ya se señaló anteriormente pueden ser deducidos para efectos de la determinación del impuesto a la renta.

Asimismo, podría deducir de su Impuesto a la Renta la pérdida del bien en la medida que quedara demostrado en el procedimiento judicial correspondiente que se trató de un acto realizado en su contra por un trabajador suyo, en la medida que no sea indemnizada.

- $\quad$ Consecuencias para el destinatario:

Como ya vimos, se trata de una tercera persona en el contrato suscrito entre el remitente y la empresa de transporte pero que se ve perjudicado por no recibir los bienes de manera oportuna (o no recibirlos); situación por la que puede ser indemnizado por lucro cesante, la misma que estará afecta al Impuesto a la Renta toda vez que no está destinada a la reposición de un bien.

\section{b.3) Si el bien se pierde por culpa del destinatario (comprador de los insumos químicos, tercero en la obligación de prestar el servicio de transporte).}

El artículo $1156^{\circ}$ del Código Civil dispone que si la prestación resulta imposible sin culpa de las partes, la obligación del deudor queda resuelta. El deudor debe devolver en este caso al acreedor lo que por razón de la obligación haya recibido.

En este supuesto, lo que la norma dispone es que la situación se retrotraiga hasta antes del nacimiento de las obligaciones contraídas.

Sin embargo, no puede dejar de aplicarse la teoría de la indemnización, por lo que cada parte que haya sufrido algún daño podrá reclamar el resarcimiento correspondiente.

- Consecuencias para el remitente:

La indemnización que puede recibir podría incluir el monto de los bienes perdidos (insumos químicos) lo cual impediría que esta pérdida pueda ser deducible para efectos de la determinación de Impuesto a la Renta. 
Asimismo, todo monto percibido que no está destinado a la reposición del bien, incluido el monto que supere su costo computable, estará afecto al referido impuesto.

- $\quad$ Consecuencia para el transportista:

Al igual que en el caso del remitente, puede recibir una indemnización que lo compense por la pérdida de su vehículo (daño emergente) y el lucro cesante.

De ser así, ya no podrá deducir el valor de la pérdida para la determinación del Impuesto a la Renta, y todo monto que exceda esta reposición se encuentra gravada con dicho impuesto.

- $\quad$ Consecuencias para el destinatario:

No solo deja de recibir los bienes sino que además debe cancelar las indemnizaciones mencionadas en los párrafos precedentes, las mismas que no podrán ser deducidas del impuesto a la renta, toda vez que no se derivan del incumplimiento de una obligación a su cargo (recordemos que él es una tercera persona en el contrato de transporte), por lo que se trata de un gasto no vinculado de ninguna manera a la generación de renta.

Ahora bien, que sucede si este vehículo no pertenecía a la empresa de transportes? Entra en juego una persona más perjudicada por la acción de incautación, la misma que, lejos de poder recuperar el bien podrá iniciar acciones contra la empresa de transportes y recibirá algún pago como indemnización por la pérdida sufrida. A este tercero, en todo caso, también le será de aplicación el inciso d) del artículo $37^{\circ}$ de la Ley del Impuesto a la Renta, en la medida que se cumplan todos los requisitos ya señalados anteriormente.

2.1.1.2 Incautaciones administrativas (como medida sancionatoria). Como se explicó anteriormente, en estos supuestos, contenidos en el Decreto Supremo Nº 0102015-EF, la administración tributaria tendrá que proceder a efectuar el procedimiento administrativo sancionado previsto en la Ley del Procedimiento Administrativo General para poder imponer la sanción de incautación.

Lo que diferencia el análisis de esta situación de los argumentos señalados precedentemente es que el inciso c) del artículo $44^{\circ}$ de la Ley del Impuesto a la Renta 
establece que no son deducibles para la determinación de la renta imponible de tercera categoría las multas, recargos, intereses moratorios previstos en el Código Tributario y, en general, sanciones aplicadas por el Sector Público Nacional.

En consecuencia, el valor de los bienes incautados no podrá ser deducido bajo ninguna consideración.

\subsubsection{Bienes adquiridos con el producto de actividades ilícitas}

De acuerdo a la Oficina de las Naciones Unidad contra las Drogas y el Crimen, el Lavado de Activos es un delito que consiste en dar una apariencia de origen legítimo o lícito a bienes - dinerarios o no, que en realidad son productos o "ganancias" de delitos graves (UNODC, 2015, párr. 1).

De igual manera, la Superintendencia de Banca, Seguros y AFP señala que el lavado de activos es el conjunto de operaciones realizadas por una o más personas naturales o jurídicas, tendientes a ocultar o disfrazar el origen ilícito de bienes o recursos que provienen de actividades delictivas. Se desarrolla usualmente mediante la realización de varias operaciones, encaminadas a encubrir cualquier rastro del origen ilícito de los recursos (SBS, párr. 1)

Dado que el objetivo de estas operaciones es ocultar el origen ilícito de los fondos que permitieron adquirir los bienes, contablemente estos aparecerán como activos de la empresa.

No obstante ello, es evidente que estos bienes serán incautados a favor del Estado $^{20}$, por lo que, la incautación efectuada por la SUNAT se vería inmersa en el proceso penal por enriquecimiento indebido.

Sin embargo, no debemos de dejar de observar que estos bienes, antes de su incautación bien pueden haber sido usados en actividades lícitas que generaban renta a favor del Usuario/delincuente.

En efecto, recordemos que el lavado de dinero implica diversas acciones que pretenden, en primer orden, colocar el dinero en el sistema financiero o en negocios legales; luego buscará la forma de "trabajar" dicho dinero a efecto de alejarlo de sus orígenes ilícitos para, finalmente, integrarlo a la economía nacional bajo un manto de legalidad.

20 Se entiende que los agentes del delito no tiene derecho verdadero sobre los bienes, toda vez que estos fueron adquiridos por mecanismos contrarios al derecho. 
Surge entonces la pregunta sobre la carga impositiva aplicable a las rentas provenientes de las transacciones efectuadas durante ese largo recorrido.

El artículo $52^{\circ}$ de la Ley del Impuesto a la Renta establece que se presume que los incrementos patrimoniales cuyo origen no puedan ser justificados por el deudor tributario, constituyen renta no declarada por éste. Los incrementos patrimoniales no podrán ser justificados con:

a) Donaciones recibidas $\mathrm{u}$ otras liberalidades que no consten en escritura pública o en otro documento fehaciente.

b) Utilidades derivadas de actividades ilícitas.

c) El ingreso al país de moneda extranjera cuyo origen no esté debidamente sustentado.

d) Los ingresos percibidos que estuvieran a disposición del deudor tributario pero que no los hubiera dispuesto ni cobrado, así como los saldos disponibles en cuentas de entidades del sistema financiero nacional o del extranjero que no hayan sido retirados.

e) Otros ingresos, entre ellos, los provenientes de préstamos que no reúnan las condiciones que señale el reglamento.

La figura del incremento patrimonial injustificado responde a la teoría del consumo más incremento patrimonial, según la cual no interesa si el ingreso del contribuyente proviene de un flujo de riqueza o de actividades con terceros. En este caso solo se tendrá en cuenta los cambios ocurridos en el patrimonio del contribuyente en el año fiscal para presumir que todo incremento corresponde a renta no declarada, sin importar el origen de la misma.

En efecto, de acuerdo a dos sentencias ${ }^{21}$, bastante conocidas, emitidas por el Tribunal Constitucional se estableció, entre otros, que para la aplicación del artículo $52^{\circ}$ de la Ley del Impuesto a la Renta no es relevante el origen - lícito o ilícito - del incremento patrimonial por tres razones:

Primero, porque de acuerdo con el artículo $74^{\circ}$ de la Constitución, no es función de la administración tributaria, no tiene facultades para determinar la procedencia lícita o ilícita de una renta específica; es más, sería absurdo y contraproducente pretender que se le exija a la administración tributaria evaluar y determinar el título jurídico del incremento patrimonial.

${ }^{21}$ STC 04985-2007-PA/TC y 04382-2007-PA/TC. 
Segundo, que la administración tributaria tenga que verificar previamente si el incremento patrimonial no justificado proviene de rentas licitas o ilícitas resulta siendo una exigencia irrazonable que tornaría en inviable la realización de sus facultades tributarias.

Tercero, porque el impuesto a la renta grava hechos o actividades económicas, no las conductas de las personas en función si estas son lícitas o ilícitas; de lo contrario, se establecería un antecedente negativo muy grave porque para que una persona se exima de sus obligaciones tributarias bastaría que esta alegue la ilicitud de sus utilidades. (Robles Moreno, 2008, I-8)

Como puede deducirse entonces, los bienes adquiridos a través de dinero ilícito darán lugar a la aplicación de la figura del incremento patrimonial no justificado, pasando a constituir renta gravada.

Ahora bien, es importante señalar que Tribunal Constitucional también señaló que carece de sustento el argumento del demandante en el sentido que la determinación del impuesto a la renta constituye una doble sanción, toda vez que en el proceso penal ya se les había impuesto una condena (consistente en incautación y comiso de los fondos adquiridos por los delitos de cohecho pasivo propio y peculado), toda vez que considera obvio que la determinación del impuesto a la renta no constituye una sanción penal y porque la función de la administración tributaria no es imponer penas. Como tampoco por su propia naturaleza y por los bienes jurídicos que protege, el proceso penal no puede ser considerado equiparable al procedimiento de determinación tributaria.

En conclusión, si los bienes adquiridos de manera ilegal constituyen renta gravada, por lo que se deberá aplicar a ellos las consideraciones señaladas con anterioridad.

\subsubsection{Bienes incautados que no pertenecen al Usuario}

Incluiremos en este acápite el supuesto de la incautación de bienes - mayoritariamente medios de transporte - en poder del Usuario pero que no le pertenecen. Puede ser porque media un contrato de alquiler, de préstamo o incluso de arrendamiento financiero.

Ante la incautación de estos bienes es evidente que el tercero/propietario se verá afectado en su patrimonio, sin embargo, podrá repetir contra su contraparte para conseguir la compensación correspondiente. 
Los pagos mensuales que el usuario debía realizar por el uso del bien podrán ser deducibles para efectos del impuesto a la renta únicamente hasta la oportunidad de la incautación, toda vez que hasta ese momento estos se encontraban vinculados a la generación de rentas gravadas. Posteriormente, cuando ya son incautados y dejan de producir renta, esta deducción dejará de ser posible porque desaparece la relación de causalidad que debe existir.

\subsection{Impuesto General a las Ventas}

Este impuesto grava, entre otros, la venta en el país de bienes muebles, concepto que incluye, según lo establecido por el numeral 2 del artículo $3^{\circ}$ de la Ley del I.G.V., al retiro de bienes que efectúe el propietario, socio o titular de la empresa o la empresa misma, incluyendo los que se efectúen como descuento o bonificación.

Se exceptúa de este concepto, es decir, no constituye retiro de bienes aquellos efectuados como consecuencia de la desaparición, destrucción o pérdida de bienes debidamente acreditada.

Para tal efecto, el numeral 4 del artículo $2^{\circ}$ del Reglamento establece que la pérdida, desaparición o destrucción de bienes por caso fortuito o fuerza mayor, así como por delitos cometidos en perjuicio del contribuyente por sus dependientes o terceros se acreditará con el informe emitido por la compañía de seguros, de ser el caso, y con el respectivo documento policial el cual deberá ser tramitado dentro de los 10 días hábiles de producidos los hechos o que se tome conocimiento de la comisión del delito, antes de ser requerido por la SUNAT, por ese período.

Como puede apreciarse los bienes incautados al amparo del Decreto Legislativo $\mathrm{N}^{\circ} 1126$ bien podrían ser considerados como retiro de bienes e la medida que no se cumpla con las premisas detalladas en el párrafo precedente.

En efecto, el Diccionario de la Lengua Española define como “destrucción” el quitar a alguien los medios con que se mantenía o estorbarle que los adquiera; mientras que la definición de "pérdida" abarca el dejar de tener o no hallar aquello que se poseía, sea por culpa o descuido del poseedor, por contingencia o desgracia. Por su parte, las normas glosadas prevén que estas circunstancias obedezcan a delitos cometidos en perjuicio del contribuyente por sus dependientes o terceros.

Ahora bien, para que esta figura no sea considerada como retiro de bienes, se deberá acreditar con el informe emitido por la compañía de seguros (respecto de la pérdida del bien asegurado que en estricto habría que evaluar si la incautación configura 
como "hecho asegurable" y el informe policial referido al delito efectuado por el trabajador o el tercero en contra del Usuario/contribuyente. Es decir este último deberá efectuar la denuncia correspondiente contra el autor del delito.

Finalmente, debe mencionarse que de acuerdo a lo dispuesto en el artículo $20^{\circ}$ de la Ley del Impuesto General a las Ventas, el impuesto que grava el retiro de bienes en ningún caso podrá ser deducido como crédito fiscal, ni podrá ser considerado como costo o gasto por el adquirente.

Asimismo, el numeral 6 del artículo $2^{\circ}$ del Reglamento de la Ley del Impuesto General a las Ventas establece que en ningún caso el impuesto que grava el retiro de bienes podrá trasladarse al adquirente de los mismos. 


\section{CONCLUSIONES}

- Las incautaciones que realiza SUNAT al amparo del Decreto Legislativo $N^{\circ} .1126$ implican la desposesión de los bienes a favor del Estado Peruano. Situación que tiene efectos patrimoniales y tributarios en la esfera del usuario/contribuyente.

- Las consecuencias que se derivan de estas incautaciones dependerán si estamos ante un indicio de posible delito penal, o ante una infracción administrativa.

- Dado que las normas prevén que la incautación procede ante la detección de una situación que constituye indicio del delito de Tráfico Ilícito de Drogas y ante el incumplimiento de infracciones administrativas, el procedimiento y las consecuencias de estas dependerán de la norma que se aplica.

- Así, si estamos ante el indicio de un delito penal la incautación no constituye una sanción, sino la aplicación directa e inmediata de la norma legal.

- Muy por el contrario, si nos encontramos ante el incumplimiento de una norma administrativa, la sanción de incautación podrá ser aplicada luego de culminado el procedimiento administrativo sancionador previsto en la Ley del Procedimiento Administrativo General.

- Los supuestos que determinan la incautación penal (las que se efectúan ante el indicio de un posible delito de Tráfico Ilícito de Drogas) se encuentran detallados en el Decreto Legislativo $N^{\circ} .1126$.

- Las causales que dan lugar a la aplicación de la incautación por incumplimiento de normas administrativas se encuentras referidas en el Decreto Supremo N ${ }^{\circ}$ 0102015-EF.

- Las consecuencias de la incautación también variarán en caso se trate de bienes que proceden de actividades lícitas desarrolladas por el usuario o de productos/medios de transporte adquiridos con dinero proveniente de actividades ilícitas (lavado de dinero).

- La pérdida de los bienes incautados podrá ser deducible para efectos de la determinación del Impuesto a la Renta, en la medida que se demuestre que ésta ocurrió por un accionar en contra del usuario/contribuyente por parte de terceros o de dependientes de la empresa. 
- La indemnización que se perciba por cualquier medio, tendiente a reponer el bien perdido (daño emergente) estará afecta al Impuesto a la Renta en la parte que sobrepase el costo computable del bien que se repondrá.

- La indemnización que se perciba por cualquier medio tendiente a reparar el lucro cesante estará afecta al Impuesto a la Renta.

- El pago de indemnizaciones que se realice por cualquier concepto podrá ser deducido para efecto de la determinación del Impuesto a la Renta, en la medida que la obligación de su pacto esté expresamente pactada.

- Tratándose de las incautaciones que se aplican como medidas sancionatorias, el valor de los bienes incautados no podrá ser deducido para efectos de la determinación del Impuesto a la Renta.

- Todo incremento patrimonial no justificado se considera renta no declarada, independiente del origen de este.

- Los bienes que se pierden como consecuencia de delitos cometidos en perjuicio del usuario/contribuyente por terceros o sus dependientes podrán ser considerados como retiro de bienes, y por lo tanto, afectos al Impuesto General a las Ventas, en la medida que no se acredite con el informe de la compañía de seguros y de la Policía.

- En ningún caso el impuesto que grava el retiro de bienes puede ser considerado como costo o gasto para efectos del Impuesto a la Renta 


\section{REFERENCIAS}

Antezana Rivera, J. (2011). El Uso Indebido de los Insumos Químicos. En Narcotráfico: amenaza al Crecimiento Sostenible del Perú. Estudios sobre coca, cocaína, seguridad $y$ desarrollo (pp.155-162) ( $2^{\circ}$ ed.). Lima: Macroconsult S.A.

Carrasco Buleje, L. y Torres Cárdenas, G. (2014). Manual del Sistema Tributario. Volumen II. Lima: Centro de Investigación Jurídico Contable.

CICAD (3 de Mayo de 2010). Estrategia Hemisférica sobre Drogas. Washington DC: OEA. Recuperado de: http://www.cicad.oas.org/apps/Document.aspx?Id=954

Código Civil (Perú). Decreto Legislativo Nº 295 (25 de julio de 1984). Recuperado del sitio de Internet del Sistema Peruano de Información Jurídica: http://spij.minjus.gob.pe/CLP/contenidos.dll?f=templates\&fn=default$\underline{\text { codcivil.htm\&vid=Ciclope:CLPdemo }}$

Comisión Nacional para el Desarrollo y Vida sin Drogas - DEVIDA (2014). Perú rumbo la Bicentenario. Compendio normativo sobre tráfico ilícito de drogas y desarrollo alternativo. Lima: Observatorio Peruano de Drogas.

Comunidad Andina (30 de abril de 1986). Convenio "Rodrigo Lara Bonilla" entre los países miembros del acuerdo de Cartagena, sobre la cooperación para la prevención del uso indebido y la represión del tráfico ilícito de estupefacientes y sustancias psicotrópicas. Lima. Recuperado de: http://intranet.comunidadandina.org/Documentos/DInformativos/SGdi489.doc

Comunidad Andina (6-7 de Diciembre del 2004) Norma Andina para el Control de Sustancias Químicas que se utilizan en la fabricación ilícita de estupefacientes y sustancias psicotrópicas. Cuzco. Recuperado de:

https://www.google.com.pe/url?sa=t\&rct=j\&q=\&esrc=s\&source=web\&cd=1\&cad=rja \&uact=8\&ved=0ahUKEwjn7Jvpy zQAhXE7yYKHZRoA8EQFggaMAA\&url=http\% 3A\%2F\%2Fintranet.comunidadandina.org\%2FDocumentos\%2Fdecisiones\%2FDEC6 02.doc\&usg=AFQjCNGQXm0qenvcSH6UU1ffSfWu5BiQww\&sig2=zeeIT6vHeWR qljenC31MTA

Decreto Legislativo N. ${ }^{\circ} 1126$. Decreto Legislativo que establece medidas de control en los insumos químicos y productos fiscalizados, maquinarias y equipos utilizados para la elaboración de drogas ilícitas. (1 de noviembre de 2012). Lima: Diario Oficial El Peruano.

Decreto Supremo 055-99-EF. Texto Único Ordenado de la Ley del Impuesto General a las Ventas e Impuesto Selectivo al Consumo. Recuperado de: http://www.sunat.gob.pe/legislacion/igv/ley/

Decreto Supremo N. ${ }^{\circ}$ 179-2004-EF. Texto Único Ordenado de la Ley del Impuesto a la Renta. (8 de Diciembre del 2004). Recuperado de: http://www.sunat.gob.pe/legislacion/renta/ley/fdetalle.htm

Decreto Supremo N ${ }^{\circ}$ 044-2013-EF. Reglamento del Decreto Legislativo $N^{\circ} .1126$, Decreto Legislativo que establece medidas de control en los insumos químicos y productos 
fiscalizados, maquinarias y equipos utilizados para la elaboración de drogas ilícitas. (1 de marzo de 2013). Lima: Diario Oficial El Peruano.

Decreto Supremo N ${ }^{\circ}$ 010-2015-EF. Tabla de Infracciones y Sanciones por el incumplimiento de las obligaciones contenidas en el Decreto Legislativo $\mathrm{N}^{\circ} .1126$ y regula el Procedimiento Sancionador respectivo a cargo de la SUNAT. (29 de enero de 2015). Lima: Diario Oficial El Peruano.

Ley 29915 (12 de Diciembre del 2012) Delégase en el Poder Ejecutivo la Facultad de Legislar en Materia de Fortalecimiento y Reforma Institucional del Sector Interior y de Defensa Nacional. Lima: Diario El Peruano. Recuperado de:

http://busquedas.elperuano.com.pe/normaslegales/delegase-en-el-poder-ejecutivo-lafacultad-de-legislar-en-ma-ley-n-29915-840032-1/

OEA (7 de Junio del 2013). Declaración de Antigua Guatemala "Por una Política Integral frente al Problema Mundial de las Drogas en las Américas". Recuperado de: http://www.oas.org/es/centro_noticias/comunicado_prensa.asp?sCodigo=D-010

Oficina de las Naciones Unidas contra la Droga y el Delito - UNODC. Perú y Ecuador. Lavado de Activos. Recuperado de: https://www.unodc.org/peruandecuador/es/02AREAS/DELITO/lavado-deactivos.html

Osterling Parodi, F. (sin fecha). Obligaciones con Cláusula Penal. Recuperado de: http://www.osterlingfirm.com/Documentos/articulos/Obligaciones\%20con\%20clausul a\%20penal.pdf

Real Academia Española (2014). Sanción. En Diccionario de la lengua española (23 ed.). Recuperado de: http://dle.rae.es/?id=XBPPICw

Robles Moreno, C. del P. (Agosto del 2008). Impuesto a la Renta sobre las actividades ilícitas a propósito de las sentencias del Tribunal Constitucional sobre el caso Hermoza Ríos. Actualidad Empresarial. (164). Recuperado de: http://aempresarial.com/web/revitem/1_8386_61350.pdf

SUNAT (10 de Marzo del 2003). Informe $\mathrm{N}^{\circ}$ 091-2003-SUNAT. Recuperado de: http://www.sunat.gob.pe/legislacion/oficios/2003/oficios/i0912003.htm

Superintendencia de Banca, Seguros y AFP - SBS. Lavado de Activos. Recuperado de: http://www.sbs.gob.pe/prevencion-de-lavado-activos/preguntas-frecuentes/48

Superintendencia Nacional de Aduanas y de Administración Tributaria - SUNAT. Consultas Tributarias. Recuperado de: http://www.sunat.gob.pe/legislacion/oficios/2003/oficios/i0912003.htm

UNODC, (1988) Convención de las Naciones Unidas contra el Tráfico Ilícito de Estupefacientes y Sustancias Sicotrópicas. Viena. Recuperado de: https://www.unodc.org/pdf/convention_1988_es.pdf 


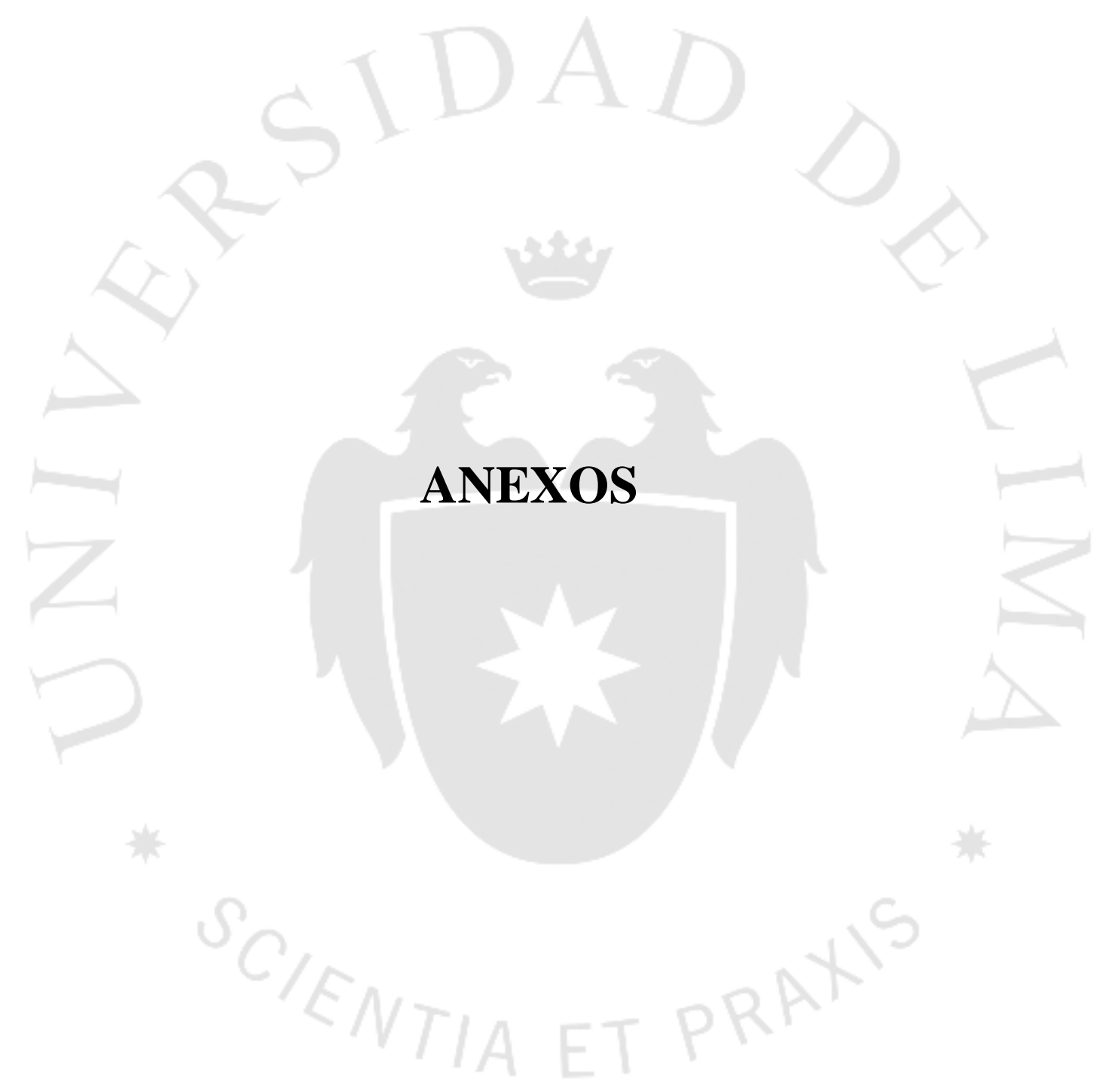




\section{ANEXO 1: Cuadro de Resumen - Contrato Compra - Venta}

\begin{tabular}{|l|l|l|}
\hline & \multicolumn{2}{|c|}{ culpa del vendedor } \\
\hline venpecto de los bienes & Respecto de la indeminización \\
\hline & $\begin{array}{l}\text { Pierde los bienes } \\
\text { Deducible como gasto } \\
\text { si es acción de terceros } \\
\text { No deducible como } \\
\text { gasto si es acción } \\
\text { propia } \\
\text { No recibe } \\
\text { contraprestación por lo } \\
\text { que no hay renta }\end{array}$ & $\begin{array}{l}\text { Paga indemnización } \\
\text { Deducible como gasto }\end{array}$ \\
\hline Comprador & $\begin{array}{l}\text { No recibe bienes } \\
\text { No paga } \\
\text { contraprestación }\end{array}$ & $\begin{array}{l}\text { Recibe indemnización por el } \\
\text { lucro cesante, afecto al } \\
\text { Impuesto a la Renta }\end{array}$ \\
\hline Transportista & $\begin{array}{l}\text { Pierde vehículo } \\
\text { Deducible por ser acto } \\
\text { de tercero en su contra }\end{array}$ & $\begin{array}{l}\text { Recibe Indemnización por } \\
\text { daño emergente gravado } \\
\text { con el Impuesto a la Renta } \\
\text { en la medida que supere el } \\
\text { costo computable } \\
\text { Recibe indemnización por } \\
\text { Iucro cesante gravado con el } \\
\text { Impuesto a la Renta }\end{array}$ \\
\hline & \begin{tabular}{l} 
Impenta \\
\hline
\end{tabular} & \\
\hline
\end{tabular}

\begin{tabular}{|c|c|}
\hline \multicolumn{2}{|c|}{ culpa del comprador } \\
\hline Respecto de los bienes & Respecto de la indeminización \\
\hline No entrega bienes & $\begin{array}{l}\text { Recibe indemnización } \\
\text { (contraprestación) por lucro } \\
\text { cesante, afecto al Impuesto a } \\
\text { la Renta }\end{array}$ \\
\hline $\begin{array}{l}\text { Pierde los bienes } \\
\text { Deducible si es acción } \\
\text { de tercero } \\
\text { No deducible si es } \\
\text { acción propia }\end{array}$ & $\begin{array}{l}\text { Paga la contraprestación } \\
\text { (indeminzación) } \\
\text { Deducible como gasto }\end{array}$ \\
\hline $\begin{array}{l}\text { Pierde vehículo } \\
\text { Deducible por ser acto } \\
\text { de tercero en su contra }\end{array}$ & $\begin{array}{l}\text { Recibe Indemnización por } \\
\text { daño emergente gravado con } \\
\text { el Impuesto a la Renta en la } \\
\text { medida que supere el costo } \\
\text { computable } \\
\text { Recibe indemnización por } \\
\text { lucro cesante gravado con el } \\
\text { Impuesto a la Renta }\end{array}$ \\
\hline
\end{tabular}

\begin{tabular}{|c|c|}
\hline \multicolumn{2}{|c|}{ culpa del transportista } \\
\hline Respecto de los bienes & Respecto de la indeminización \\
\hline $\begin{array}{l}\text { Pierde los bienes } \\
\text { Deducible por ser acto } \\
\text { de tercero } \\
\text { No recibe } \\
\text { contraprestación por lo } \\
\text { que no hay renta } \\
\text { imponible }\end{array}$ & $\begin{array}{l}\text { Recibe indemnización por } \\
\text { daño emergente. Afecta al } \\
\text { impuesto a la Renta en la } \\
\text { medida que supere el costo } \\
\text { computable } \\
\text { Recibe indemnización por } \\
\text { Iucro cesante afecta al } \\
\text { Impuesto a la Renta }\end{array}$ \\
\hline $\begin{array}{l}\text { No recibe los bienes } \\
\text { No paga } \\
\text { contraprestación }\end{array}$ & \begin{tabular}{|l} 
Recibe indemnización por \\
Iucro cesante afecta al \\
Impuesto a la Renta
\end{tabular} \\
\hline $\begin{array}{l}\text { Pierde vehículo } \\
\text { Deducible si es acción } \\
\text { de tercero } \\
\text { No deducible si es } \\
\text { acción propia }\end{array}$ & $\begin{array}{l}\text { Paga indemnización por } \\
\text { daño emergente y lucro } \\
\text { cesante al vendedor } \\
\text { Paga indemnización por } \\
\text { lucro cesante al comprador } \\
\text { Si recibe indemnización } \\
\text { (seguro) es aefecto al } \\
\text { Impuesto a la Renta en la } \\
\text { medida que supere el costo } \\
\text { computable }\end{array}$ \\
\hline
\end{tabular}




\section{ANEXO 2: Cuadro de Resumen - Contrato de Transporte}

\begin{tabular}{|l|l|l|}
\hline \multicolumn{2}{|c|}{ Por culpa del remitente } \\
\hline $\begin{array}{l}\text { Remitente } \\
\text { Acreedor }\end{array}$ & $\begin{array}{l}\text { Respecto de los bienes } \\
\text { los bienes }\end{array}$ & $\begin{array}{l}\text { Respecto de la indemnización } \\
\text { Debe pagar la } \\
\text { contraprestación } \\
\text { (indemnización) que es } \\
\text { deducible para efectos del } \\
\text { Impuesto a la Renta }\end{array}$ \\
\hline $\begin{array}{l}\text { Transportista } \\
\text { Deudor }\end{array}$ & $\begin{array}{l}\text { Pierde el vehículo. } \\
\text { Deducible para efectos } \\
\text { del Impuesto a la Renta } \\
\text { por ser acción de tercero }\end{array}$ & $\begin{array}{l}\text { Recibe indemnización de } \\
\text { daño emergente, afecta al } \\
\text { Impuesto a la Renta si } \\
\text { supera el costo } \\
\text { computable del bien } \\
\text { Recibe indemnización por } \\
\text { Iucro cesante, afecta al } \\
\text { Impuesto a la Renta }\end{array}$ \\
\hline Destinatario & No recibe los bienes & $\begin{array}{l}\text { Recibe indemnización por } \\
\text { Iucro cesante, afecta al } \\
\text { Tercero }\end{array}$ \\
\hline
\end{tabular}

\begin{tabular}{|c|c|}
\hline \multicolumn{2}{|c|}{ Por culpa del Transportista } \\
\hline $\begin{array}{l}\text { Respecto de los bienes } \\
\text { No recibe el traslado de } \\
\text { los bienes }\end{array}$ & $\begin{array}{l}\text { Respecto de la indemnización } \\
\text { Recibe indemnización por } \\
\text { el lucro cesante afecta al } \\
\text { Impuesto a la Renta. }\end{array}$ \\
\hline $\begin{array}{l}\text { Pierde el vehículo. } \\
\text { Deducible para efectos } \\
\text { del Impuesto a la Renta } \\
\text { en la medida que } \\
\text { acredite que fue acción } \\
\text { de un tercero } \\
\text { (dependiente) } \\
\text { No deducible para } \\
\text { efectos del Impuesto a } \\
\text { la Renta en la medida }\end{array}$ & \begin{tabular}{|l} 
Debe pagar \\
indemnización por lucro \\
cesante al remitente y al \\
destinatario de los \\
bienes, la misma que \\
podrá ser deducida del \\
Impuesto a la Renta \\
\end{tabular} \\
\hline No recibe los bienes & $\begin{array}{l}\text { Recibe indemnización por } \\
\text { lucro cesante, afecta al } \\
\text { Impuesto a la Renta }\end{array}$ \\
\hline
\end{tabular}

\begin{tabular}{|l|l|}
\hline \multicolumn{2}{|c|}{ Por culpa del destinatario } \\
\hline $\begin{array}{l}\text { Respecto de los bienes } \\
\text { No recibe el traslado } \\
\text { de los bienes }\end{array}$ & $\begin{array}{l}\text { Respecto de la indemnización } \\
\text { Recibe indemnización por } \\
\text { el lucro cesante afecta al } \\
\text { Impuesto a la Renta. }\end{array}$ \\
\hline $\begin{array}{l}\text { Pierde el vehículo. } \\
\text { Deducible para efectos } \\
\text { del Impuesto a la } \\
\text { Renta por ser acción de } \\
\text { tercero }\end{array}$ & $\begin{array}{l}\text { Recibe indemnización de } \\
\text { daño emergente, afecta al } \\
\text { Impuesto a la Renta si } \\
\text { supera el costo } \\
\text { computable del bien } \\
\text { Recibe indemnización por }\end{array}$ \\
\hline lucro cesante, afecta al \\
Impuesto a la Renta
\end{tabular} \mid \begin{tabular}{l} 
No recibe los bienes \\
$\begin{array}{l}\text { Debe pagar } \\
\text { indemnización al } \\
\text { remitente y al } \\
\text { transportista, la misma } \\
\text { que será deducible del }\end{array}$ \\
\hline
\end{tabular}

